\title{
Damage Control of High-Rise RC Building with Energy Dissipation Device
}

\author{
Nobuyuki Izumi ${ }^{1}$, Takahiro Watabe ${ }^{2}$ and Hiroyuki Takenaka ${ }^{3}$
}

Received 31 December 2004, revised 11 May 2005

\begin{abstract}
This paper reports the fact that an energy dissipation device (damage fuse) in its reinforced concrete (RC) frame can upgrade the ability to dissipate the energy created by earthquake excitations. When a damage fuse is applied to an RC frame, the fact that behavior such as cracking of attachment members and flexural yielding of reinforcing bars can reduce the effect of damage control should be taken into consideration, and the validity of performance evaluations of frames with a damage fuse and analysis models should be thoroughly examined in this light. Analysis models of RC frames with a damage fuse were found to effectively demonstrate the restoring force characteristics obtained from test results of horizontal loading. Several high-rise RC building projects have already chosen to use damage fuses to minimize serious damage to RC buildings subjected to strong earthquakes.
\end{abstract}

\section{Introduction}

The authors of this paper have studied the application of a damage fuse, which is an energy dissipation device that can minimize serious damage to high-rise reinforced concrete (RC) buildings subjected to strong earthquakes (see Fig. 1).

This paper begins by describing the objectives of damage control technology and providing an outline of energy dissipation devices in high-rise RC buildings. Next, it presents the results of a study on earthquake response displacements of RC frames with energy dissipation devices. Last, it introduces examples of high-rise $\mathrm{RC}$ buildings that use energy dissipation devices. Because of the rise in the number of condominiums that are high-rise RC structures, the contents of this paper focus on energy dissipation devices applied to pure rigid frames. Therefore, this paper does not cover specific structures such as multi-story earthquake resisting walls.

\section{Damage control technology of high-rise RC buildings}

\subsection{Objective of damage control technology}

(1) Design method of performance evaluation

The authors (Izumi et al. 2001; 2002) have recommended the performance evaluation design method for earthquake-resistant high-rise RC structures. The per-

${ }^{1}$ Group Manager, Dept. of Structural Engineering, Toda Corporation, Japan.

E-mail:nobuyuki.izumi@toda.co.jp

${ }^{2}$ Structural Engineer, Dept. of Structural Engineering, Toda Corporation, Japan.

${ }^{3}$ Engineer, Technical Research Institute, Toda Corporation, Japan. formance evaluation design method posits that seismic response values shall not exceed the serviceability, repairability and safety limit states. These three types of limit states have been ranked in order of earthquake intensities that may occur during the servicing period of the structure in question. The serviceability limit state is the limit state beyond which the building in question cannot be continuously occupied. The repairability limit state is the limit state beyond which the building in question cannot be repaired to its existing condition. The safety limit state is the limit state beyond which the damage to the building will endanger the lives of its occupants.

The serviceability of the building means that response values for possible earthquakes that rarely occur shall not exceed the serviceability limit state. The repairability of the building means that response values for possible earthquakes that quite rarely occur shall not exceed the repairability limit state. The safety of the building means that response values for possible earthquakes of utmost degree of intensity shall not exceed the safety limit state.

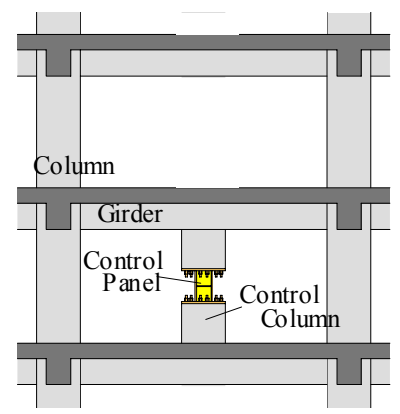

(a) RC frame with control column

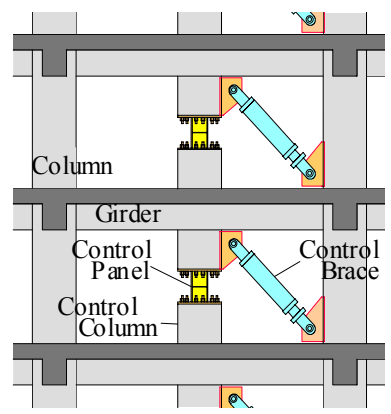

(b) RC frame with control column and control brace
Fig. $1 \mathrm{RC}$ frame with energy dissipation device. 
(2) Energy dissipation devices by using damage control technology

The earthquake resistant design of a high-rise RC condominium should be a rational design performed on each limit state and use technology that minimizes damage to its structures during strong earthquake excitations in consideration of the use and scale of buildings.

For this reason, as damage control design, the authors (Izumi et al. 2001; 2002) have presented and experimented with high strength members and the application of energy dissipation devices. By using high-strength girder bars and increasing deformation capability against high strength yield stress, plastic deformation and damage to girders can be minimized at the displacement goal design stage. On the other hand, displacements caused by earthquakes can be increased due to the decrease in hysteretic damping of girders. Therefore, use of damage control technology in the form of energy dissipation devices can control displacements.

\subsection{Outline of energy dissipation devices}

As the types of energy dissipation devices, low-yield-point steel dampers, visco-elastic dampers

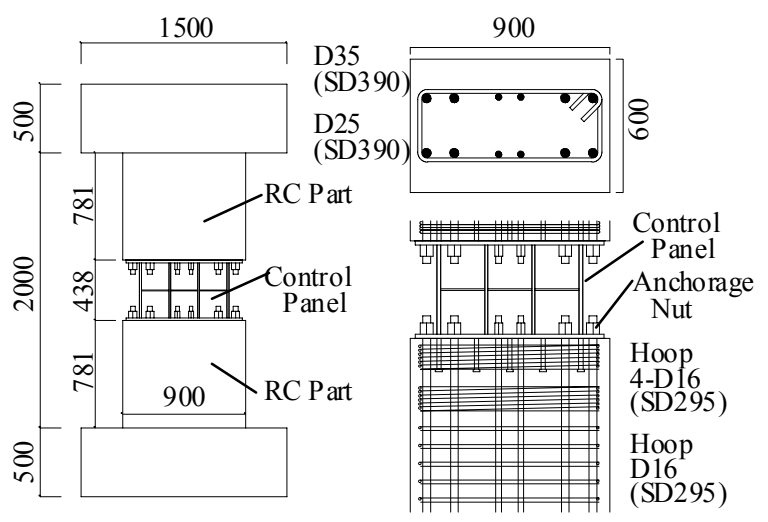

(a) Control column Type I (DHC1-235) and oil dampers can be applied to high-rise RC building. The methods for placing energy dissipation devices for $\mathrm{RC}$ frames can be selected from among stud placement, wall placement and brace placement. Examples of devices are shown in Fig. 1. A control column is an RC column that contains a panel type of damage control device at its center. As a different type of energy dissipation device (damage fuse), a brace-placing type device (control brace) can be used in addition to the stud placement type device of the control column in its RC frame.

\section{Performance evaluation of damage fuse}

\subsection{Performance evaluation of damage fuse by structural experiment}

Performance evaluations of RC members with control devices were conducted through loading tests performed not only for the damage fuses themselves but also for RC members with damage fuses. A low-yield-point steel damper (control-panel) and a visco-elastic damper were chosen as the damage fuses (Izumi et al. 2003). This paper describes the performance evaluation of a

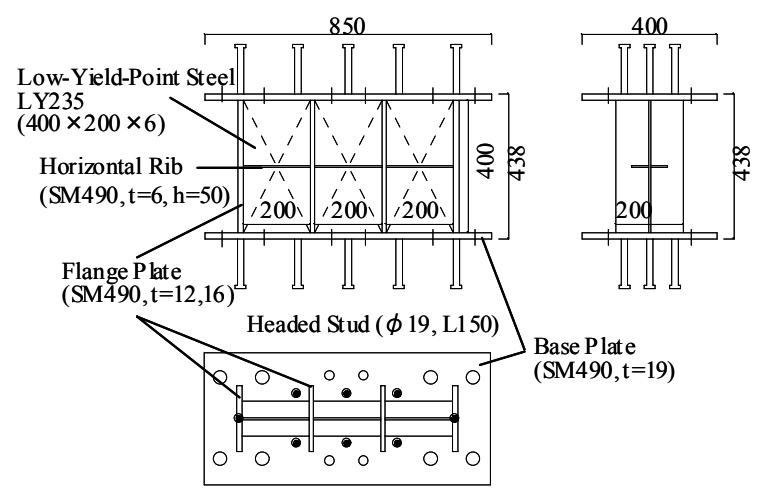

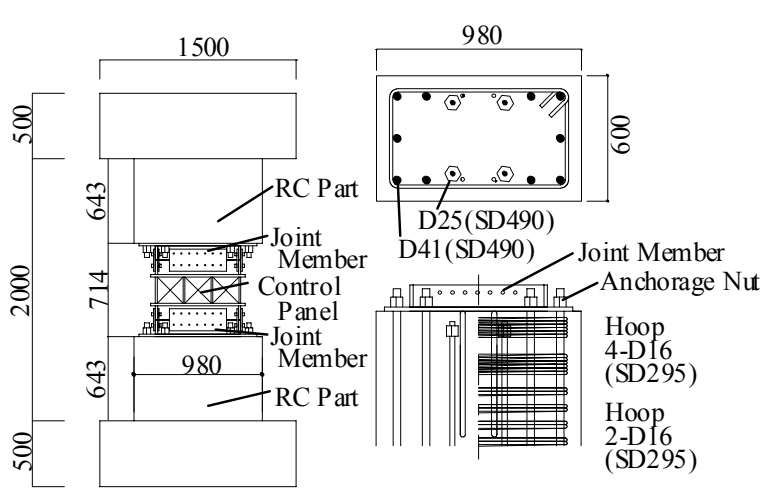

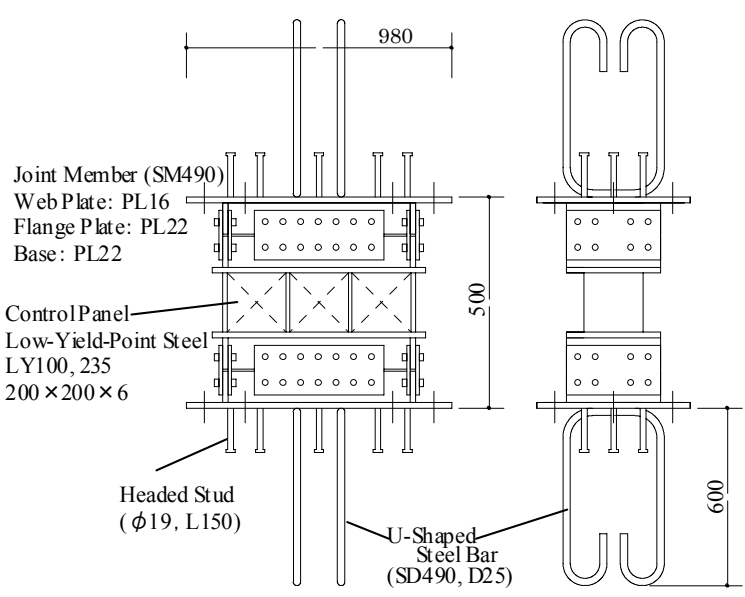

(b) Control column Type II (DHC2-23, DHC2-100)

Fig. 2 Test specimens of control column. 
stud with a low-yield point steel damper (low-yield-point steel control column).

\subsection{Structural testing of low-yield-point steel control column}

\subsubsection{Outline of experimental procedure}

(1) Experimental procedure

Control columns for two types of control-panel connections (Type I: welded connection, Type II: high-tension bolt connection) were tested for studying the restoring force characteristics of control columns.

\section{(2) Test specimens}

Two types of test specimens (control columns) are shown in Fig. 2. The control panel consists of a low-yield-point steel web plate, vertical flange plates of SM490 and base plates of SM490 at the top and the bottom of the panel. A steel plate with a first axial-yielding stress of either $100 \mathrm{~N} / \mathrm{mm}^{2}$ (LY100) or 235 $\mathrm{N} / \mathrm{mm}^{2}$ (LY235) is used as a low-yield-point steel panel. The results of material testing are listed in Table 1.

(3) Test setup (see Fig. 3) and loading sequence The loading histories were controlled by the drift angles (Rc rad.) of a control column. First, the sequence of assumed drift angles created by strong earthquakes (hereinafter LII) was repeated three times in a row. Then, the specimens were repeatedly loaded through alternate increasing loading (see Fig. 4).

\subsubsection{Outline of experimental results}

(1) Experimental progress and load-lateral drift angle relationships

The load-displacement relationships (Fig. 5) demonstrate that the behavior of control-panel deformations dominates the drift angles of the control column. At the end of the test on the DHC2-100 specimen, the residual crack width of the RC portion was approximately 0.04 mm (Fig. 6).

\section{(2) Drift angle of each portion}

The control-panel deformations dominate the drift angles of control-column as the angle value increases. Beyond the angle of $\mathrm{Rc}=1 / 100$, over $80 \%$ of drift angles are produced by shear deformations of the control panel in the DHC1 specimen.

\section{(3) Amount of energy absorption}

The amount of energy absorption of the control panel in the test specimen of the control column was equivalent to the amount of energy absorption of the control panel itself. The distortion at the connections of the control panel did not affect the energy absorption of the control column. The distortion at the connection between the control panel and the RC column could be found as the drift angles of the control column increased. However, the amount of distortion was only approximately 0.6 $\mathrm{mm}$.

Table 1 Results of material testing.

\begin{tabular}{|c|c|c|c|}
\hline $\begin{array}{c}\text { Steel Plate and Steel Bar } \\
\text { (Material) }\end{array}$ & $\begin{array}{c}\text { Young's Modulus } \\
\times 10^{5} \mathrm{~N} / \mathrm{mm}^{2}\end{array}$ & $\begin{array}{c}\text { Yield Strength } \\
\mathrm{N} / \mathrm{mm}^{2}\end{array}$ & $\begin{array}{c}\text { Tensile Strength } \\
\mathrm{N} / \mathrm{mm}^{2}\end{array}$ \\
\hline PL6 (LY100) & 2.02 & 96.3 & 261.4 \\
\hline PL6 (LY235) & 1.97 & 227.8 & 344.2 \\
\hline PL6 (SM490) & 2.03 & 419.7 & 538.2 \\
\hline D35 (SD390) & 1.90 & 430.1 & 605.8 \\
\hline D25 (SD390) & 1.87 & 436.5 & 632.6 \\
\hline D41 (SD490) & 1.96 & 519.8 & 692.1 \\
\hline D25 (SD490) & 1.96 & 555.1 & 732.5 \\
\hline D16 (SD295) & 1.86 & 360.2 & 549.1 \\
\hline
\end{tabular}

\begin{tabular}{|c|c|c|c|c|}
\hline $\begin{array}{c}\text { Control } \\
\text { Column } \\
\text { Concrete }\end{array}$ & $\begin{array}{c}\mathrm{Fc} \\
\mathrm{N} / \mathrm{mm}^{2}\end{array}$ & $\begin{array}{c}\text { Young's Modulus } \\
\times 10^{4} \mathrm{~N} / \mathrm{mm}^{2}\end{array}$ & $\begin{array}{c}\text { Compressive } \\
\text { Strength } \\
\mathrm{N} / \mathrm{mm}^{2}\end{array}$ & $\begin{array}{c}\text { Cleavage } \\
\text { Strength } \\
\mathrm{N} / \mathrm{mm}^{2}\end{array}$ \\
\hline DHC1 & 26.5 & 2.75 & 26.8 & 2.21 \\
\hline DHC2 & 35.3 & 3.13 & 34.9 & 3.29 \\
\hline
\end{tabular}

Note:

-Control Panel Web Plate (Low-Yield-Point Steel)

LY100: $100 \mathrm{~N} / \mathrm{mm}^{2}$, LY235: $235 \mathrm{~N} / \mathrm{mm}^{2}$

- Control Panel Flange Plate, Base Plate, Rib Plate: SM490

- Control Column Main Reinforcing Bar: SD390, SD490

- Control Column Reinforcing Bar: SD295 


\subsection{Analysis model of low-yield-point steel control column}

(1) Analysis model of control column

The analysis model of RC members of the control column is based on both flexural and shear deformations, whereas the model of the control panel is based on shear

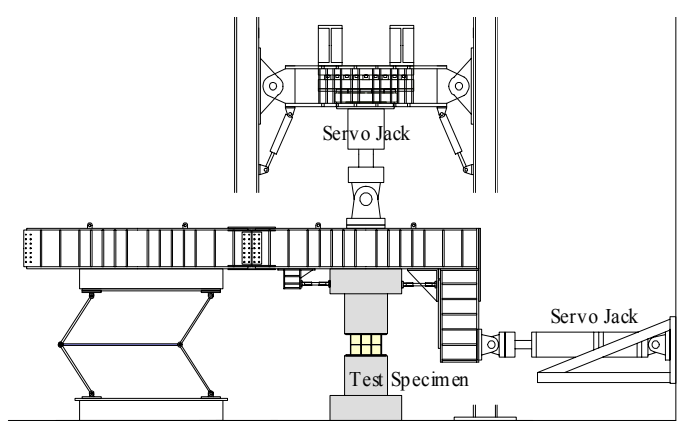

Fig. 3 Test setup.

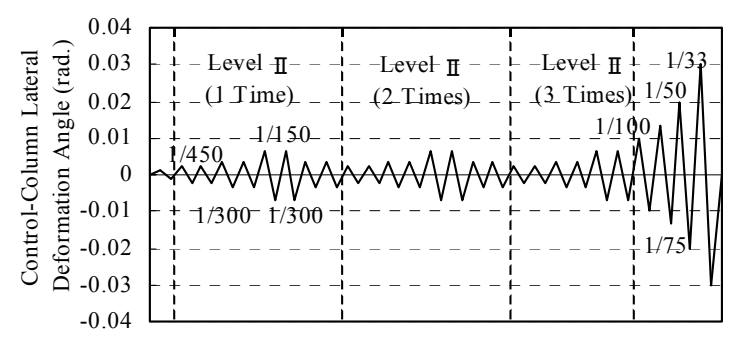

Fig. 4 Loading histories.

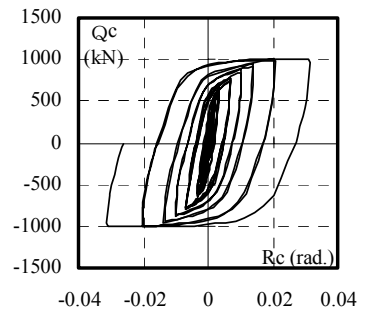

(a) DHC1-235

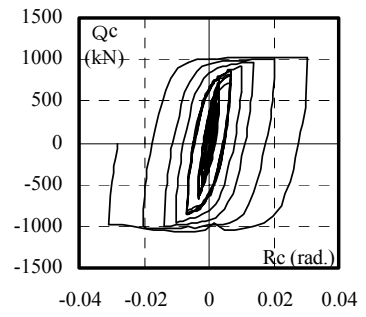

(b) DHC2-100
Fig. 5 Load-lateral drift angle relationships of control column.

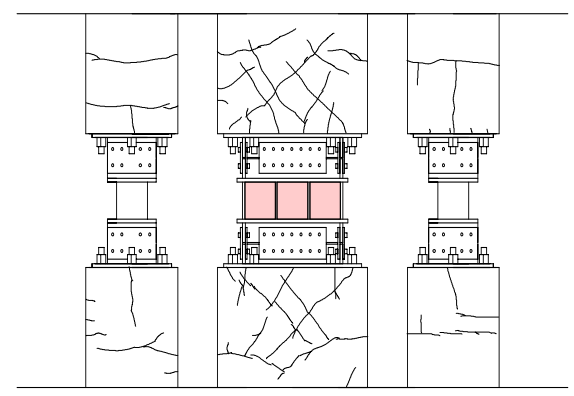

Fig. 6 Crack patterns of control column after testing. deformations, so that this analysis model can be easily applied to the elasto-plastic analysis of structures. A normal tri-linear curve model describes the restoring force characteristics of shear deformations of the control panel. The Takeda model (Takeda et al. 1970) describes the restoring force characteristics of flexural deformations of RC portions.

(2) Restoring force characteristics of control panel The skeleton curve of the control panel (see Fig. 7) is based on the shear yield point of the web plate, such as a low-yield-point steel panel. The shear strength $\left(\mathrm{Q}_{\mathrm{y} 2}\right)$ is calculated from the strength upgrading ratio $\left(\alpha_{2}\right)$ of $\mathrm{Q}_{\mathrm{y} 1}$ to $\mathrm{Q}_{\mathrm{y} 2}$. The first rigidity $\left(\mathrm{K}_{1}\right)$ is the shear rigidity of the web plate. The shear strength of the first breaking point $\left(\mathrm{Q}_{\mathrm{y} 1}\right)$ is calculated by multiplying the area of the web plate by $1 / \sqrt{3}$ of the lower limit strength of a yield point. The second rigidity $\left(\mathrm{K}_{2}\right)$ and third rigidity $\left(\mathrm{K}_{3}\right)$ are calculated from the rigidity degrading ratios, $\beta_{2}$ and $\beta_{3}$, respectively. Both the increase in strength and the rigidity of unloading are taken into consideration for the values of $\alpha_{2}, \beta_{2}$ and $\beta_{3}$. They are determined by comparing the amounts of energy absorption for the shape of the control panel (see Table 2). For the DHC2 specimen, the shear rigidities of the panel connection

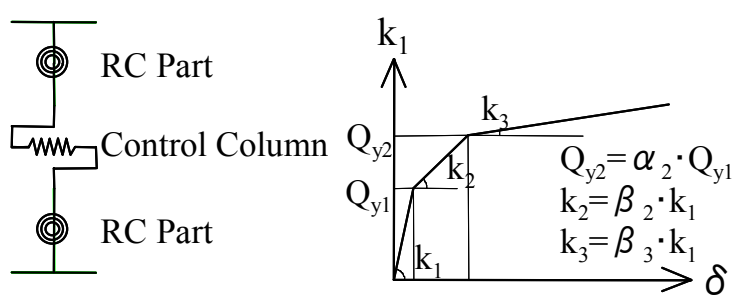

Fig. 7 Analysis model of control column.

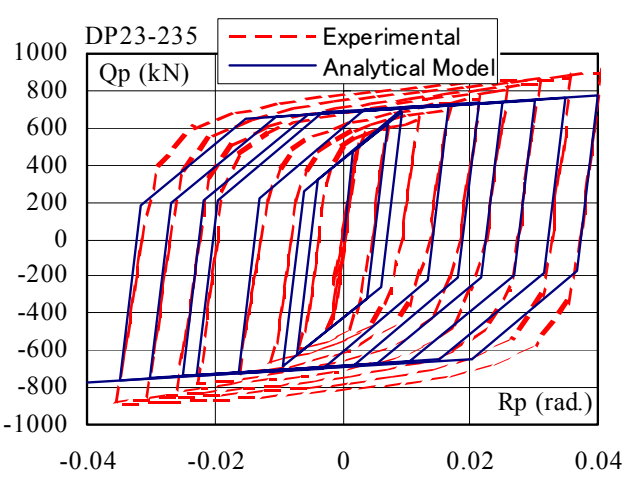

Fig. 8 Restoring force characteristics of control panel.

Table 2 Properties of skeleton curve for control panel.

\begin{tabular}{|c|c|c|c|c|c|}
\hline & $\begin{array}{c}\mathrm{Q}_{\mathrm{y} 1} \\
(\mathrm{kN})\end{array}$ & $\alpha_{2}$ & $\begin{array}{c}\mathrm{k}_{1} \\
(\mathrm{kN} / \mathrm{mm})\end{array}$ & $\beta_{2}$ & $\beta_{3}$ \\
\hline DP13-100 & 204 & 2.0 & 1430 & 0.15 & 0.012 \\
\hline DP13-235 & 448 & 1.5 & 1430 & 0.08 & 0.0075 \\
\hline DP23-235 & 448 & 1.5 & 715 & 0.1 & 0.0075 \\
\hline
\end{tabular}


members are separately taken into consideration. A comparison of the restoring force characteristics of the control panel (LY235) is shown in Fig. 8. The analysis model can effectively demonstrate the characteristics of the control panel in the regions of LII drift angles $(\mathrm{Rp} \leqq$ 0.025), whereas the analysis model is somewhat lower than the test result in the regions of large displacement since the analysis model does not directly evaluate the strength increase of vertical flanges $(10 \%$ to $20 \%$ increase at the maximum displacement). Incidentally, for the specimen using LY100, Table 2 shows the values in the regions of LII drift angles only because of the large amount of increase in strength in the regions of large displacement.

(3) Restoring force characteristics of control column The comparison of restoring force characteristics of the control column (DHC1-235) in the regions up to the maximum LII drift angle of $\mathrm{Rc}=1 / 150$ is shown in Fig. 9. The analysis model effectively demonstrates the test result. The comparison of energy absorption between the specimen (LY235) of DHC1-235 and DHC2-235 is shown in Fig. 10. At $\mathrm{Rc}=1 / 150$, the calculation values of the amount of energy absorption are approximately $85 \%$ of the test results. At $\mathrm{Rc}=1 / 50$, the calculation values are $70 \%$ to $80 \%$ of the test results. Therefore, the analysis model satisfactorily evaluates the values of the test results. Due to the increase in strength, the calculation values of the DHC2-100 (LY100) specimen obtained by using the values from Table 2 are somewhat lower than the test results in the regions of large displacement.

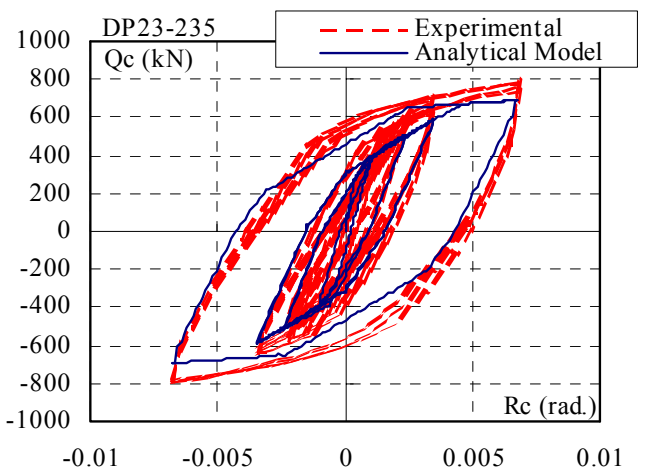

Fig. 9 Restoring force characteristics of control column.

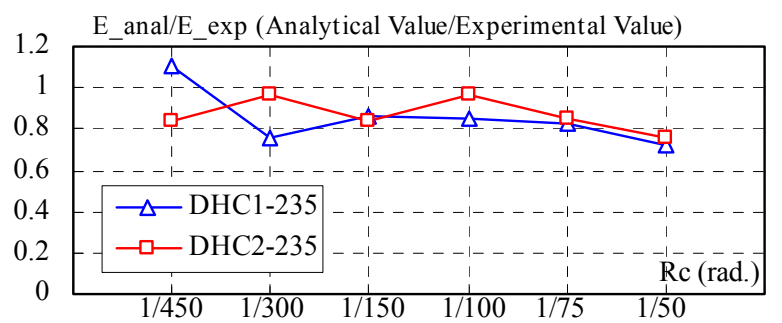

Fig. 10 Energy absorption of control column.

\section{Performance evaluation of RC frame with damage fuse}

\subsection{Performance evaluation of RC frame with control column by structural experiment}

The performance evaluations of a RC frame with a damage fuse were conducted through the loading tests of a RC frame. This chapter presents both the static and dynamic loading tests of a RC frame with a low-yield-point steel control column. For the performance evaluation of visco-elastic dampers, see the reference (Izumi et al. 2003).

\subsection{Structural experiment of RC frame with a low-yield-point steel control column}

\subsubsection{Outline of experimental procedure}

(1) Experimental procedure

A model specimen of a one-story RC frame with a low-yield-point steel control column was tested for static and dynamic loading.

\section{(2) Test specimen}

The test specimen was a half scale model of a one-story rigid RC frame consisting of columns and girders. The control column was placed in the middle of the span of its frame. The test specimen used a low-yield-point steel damper (control panel), shown in Fig. 11.

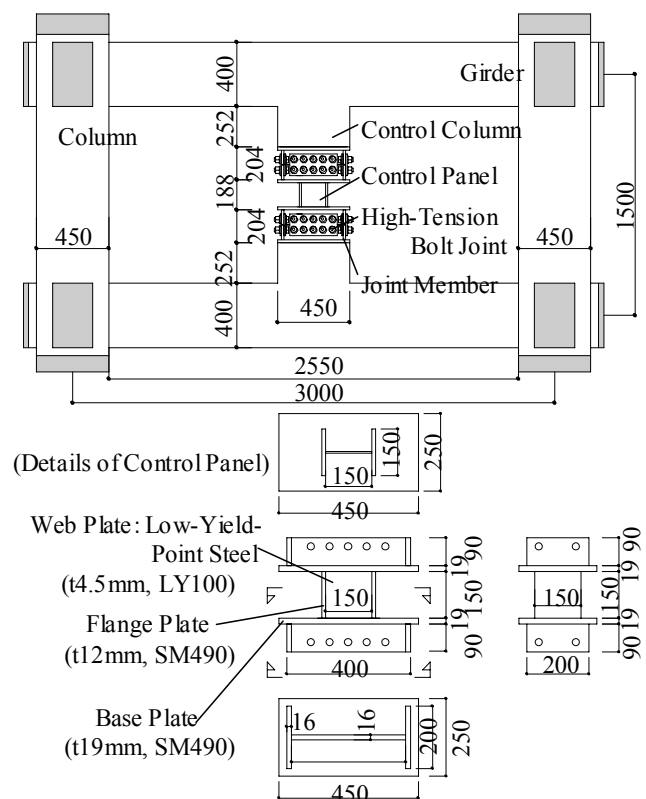

\begin{tabular}{|c|c|c|c|}
\hline & B $\times$ D $(\mathrm{mm})$ & $\begin{array}{c}\text { Main Rein- } \\
\text { forcing Bar }\end{array}$ & $\begin{array}{c}\text { Reinforcing } \\
\text { Bar }\end{array}$ \\
\hline Column & $450 \times 450$ & 16-HD22 & $4-\phi 6 @ 50$ \\
\hline Girder & $200 \times 400$ & $4+2-H D 19$ & $4-\phi 6 @ 40$ \\
\hline Control Column & $200 \times 450$ & 10 -HD19 & $\begin{array}{l}4-D 6 @ 55 \\
\text { 2-D6@40 }\end{array}$ \\
\hline \multicolumn{3}{|c}{ HD Bar: SD490, $\phi$ Bar: USD685, D Bar: SD295 }
\end{tabular}

Fig. 11 Test specimen of frame with control column. 
The control panel consisted of a low-yield-point steel web plate (yield strength of $100 \mathrm{~N} / \mathrm{mm}^{2}$ ), vertical flange plates of SM490 and base plates of SM490 at the top and the bottom of the panel. The results of material testing are listed in Table 3.

(3) Test Setup and loading sequence (see Fig. 12 and Fig. 13)

First, the static and dynamic loading tests of an RC frame only (frame-based test) were performed prior to installing the control panel. Second, the control panel

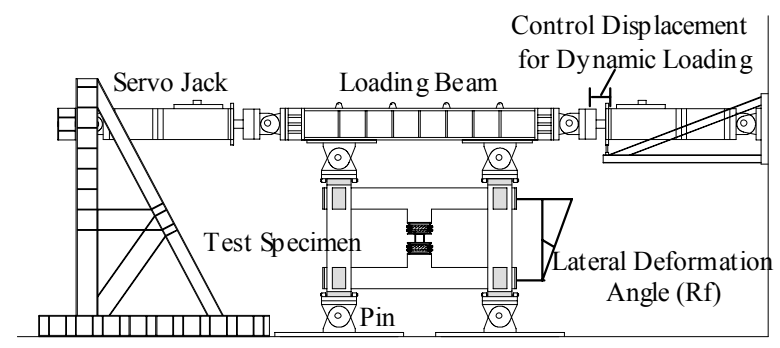

Fig. 12 Test setup.

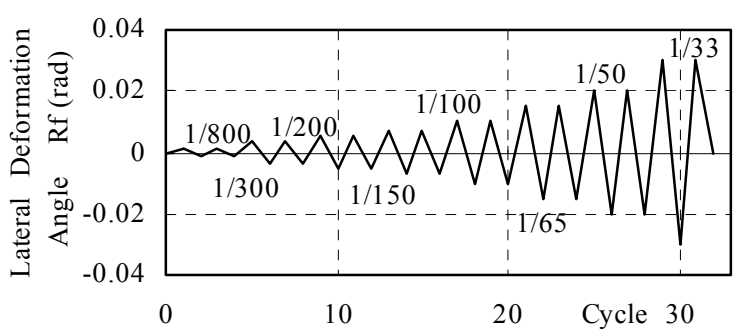

(a) Static loading

(Static test) was installed, and the dynamic loading test (dynamic test) was performed. Then, another static loading test (static test) was performed. The loading histories were controlled by drift angles ( $\mathrm{Rf}$ rad.) of the frame. The dynamic-loading test used two types of natural periods, 2 and 4 seconds, respectively. The target drift angles of two cases, 1/800 rad. and 1/300 rad., were chosen for dynamic test.

\subsubsection{Results of dynamic loading test}

\section{(1) Experimental progress}

The results of frame-based test show that flexural cracks developed at the ends of girders. However, the cracks were closed after the static test. The crack patterns after the dynamic test are similar to the results of the static test. No buckling deformations were found in a control panel.

\section{(2) Load-lateral drift angle relationships}

The load-displacement relationships for the frame-base test and dynamic test are shown in Fig. 14. Prior to the first yielding of the reinforcing bars, the control panel can upgrade the damping performance of an $\mathrm{RC}$ frame

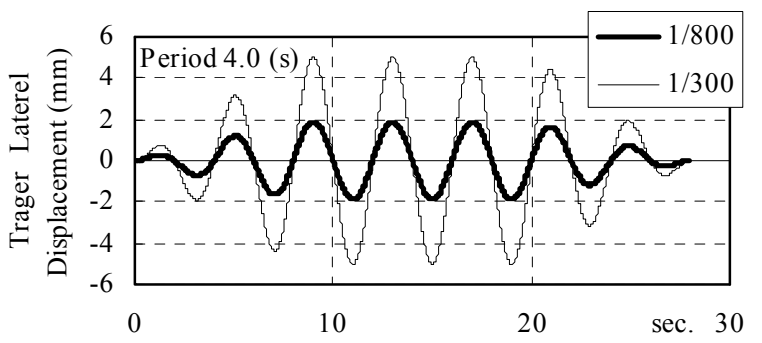

(b) Dynamic loading

(Frame-based test, dynamic test)

Fig. 13 Loading histories.

Table 3 Results of material testing ( $R C$ frame with control colum).

\begin{tabular}{|c|c|c|c|}
\hline $\begin{array}{c}\text { Steel Bar and Steel Plate } \\
\text { (Material) }\end{array}$ & $\begin{array}{c}\text { Young's Modulus } \\
\times 10^{5} \mathrm{~N} / \mathrm{mm}^{2}\end{array}$ & $\begin{array}{c}\text { Yield Strength } \\
\mathrm{N} / \mathrm{mm}^{2}\end{array}$ & $\begin{array}{c}\text { Tensile Strength } \\
\mathrm{N} / \mathrm{mm}^{2}\end{array}$ \\
\hline D22 (SD490) & 1.93 & 509 & 685 \\
\hline D19 (SD490) & 1.92 & 523 & 666 \\
\hline$\phi 6($ USD685) & 1.80 & 701 & 846 \\
\hline D6 (SD295) & 1.71 & 330 & 469 \\
\hline PL4.5 (LY100) & 1.69 & 97 & 248 \\
\hline PL6 (SM490) & 2.06 & 392 & 520 \\
\hline PL12 (SM490) & 2.06 & 384 & 530 \\
\hline PL16 (SM490) & 2.07 & 378 & 536 \\
\hline PL19 (SM490) & 2.11 & 360 & 517 \\
\hline
\end{tabular}

\begin{tabular}{|c|c|c|c|}
\hline Concrete & $\begin{array}{c}\text { Secant Modulus } \\
\times 10^{5} \mathrm{~N} / \mathrm{mm}^{2}\end{array}$ & $\begin{array}{c}\text { Compressive Strength } \\
\mathrm{N} / \mathrm{mm}^{2}\end{array}$ & $\begin{array}{c}\text { Cleavage Strength } \\
\mathrm{N} / \mathrm{mm}^{2}\end{array}$ \\
\hline $\begin{array}{c}\text { Girder } \\
\text { Control Column }\end{array}$ & 0.26 & 31 & 2.35 \\
\hline Column & 0.35 & 55 & 4.56 \\
\hline
\end{tabular}


and demonstrates the hysteresis of spindle-shaped loops as compared with the curves from the frame-based test (without control column).

\subsubsection{Results of static loading test}

\section{(1) Experimental progress}

The reinforcing bars of girders started to yield when Rf reached 1/100 rad. The maximum crack width and residual crack width were approximately $0.02 \mathrm{~mm}$ and $0.01 \mathrm{~mm}$ or less, respectively. As the type of yield mechanism, the flexural yielding of girders preceded the flexural yielding of columns, whereas not so much damage to columns could be found. The web plate of the control panel deformed out of plane when $\mathrm{Rf}$ reached 1/150 rad. The buckling modes of the web plate of the control panel could be seen while Rf increased. When $\mathrm{Rf}$ reached $1 / 33 \mathrm{rad}$. as the first cycle of negative loading, cracking of the welded boundary between the vertical flange and the panel took place. The boundary ruptured at the second cycle of positive loading (Fig. 15).

\section{(2) Load-lateral drift angle relationships}

The load-displacement relationships for the static test are shown in Fig. 16. Prior to the flexural yielding of the longitudinal reinforcing bars of the girders $(\mathrm{Rf}=1 / 100)$, the restoring force characteristics of the frame demonstrated a great capacity for energy dissipation showing spindle-shaped loops because of the yielding of the web plate of the control panel. After the cycle of $\mathrm{Rf}=1 / 100$ rad., the test results show stable

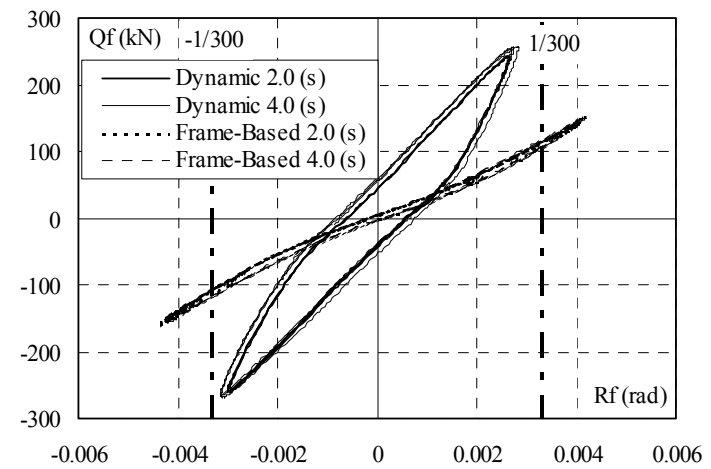

Fig. 14 Load-Lateral Drift Angle Relationships (Dynamic Test).

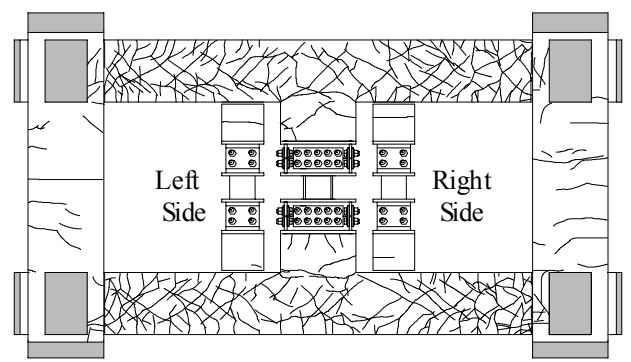

Fig. 15 Crack Patterns of Control Column after Testing (Static Test). characteristics of flexural yielding of girders.

\subsubsection{Amount of energy absorption}

The amounts of energy absorption from the dynamic test are compared with those from the frame-based test (Fig. 17). Placing a control column can increase the amount of energy absorption. Furthermore, the amount of energy absorption of the frame through static loading increases with Rf.

\subsection{Analysis model of frame with a low-yield-point steel control-column}

(1) Analysis model

The analysis model of the frame is based on the

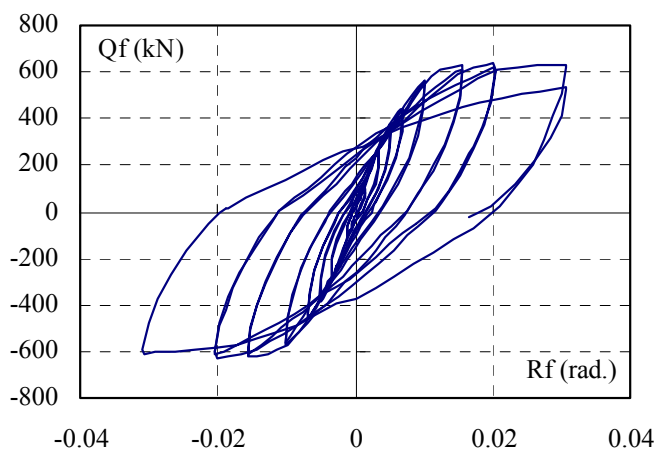

Fig. 16 Load-lateral drift angle relationships (Static test).

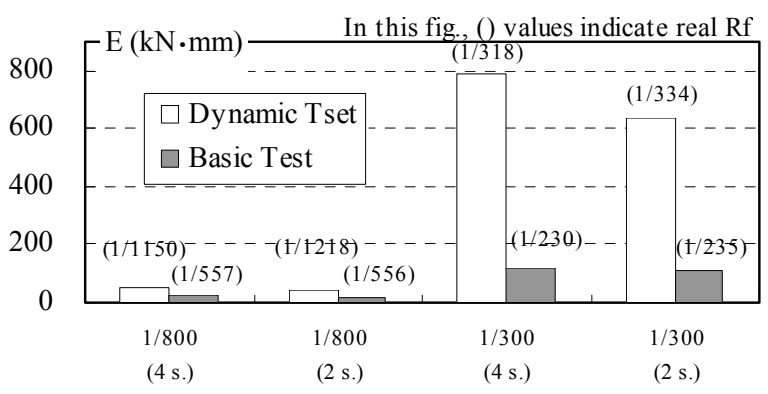

Fig. 17 Comparison of energy absorption (Dynamic test).

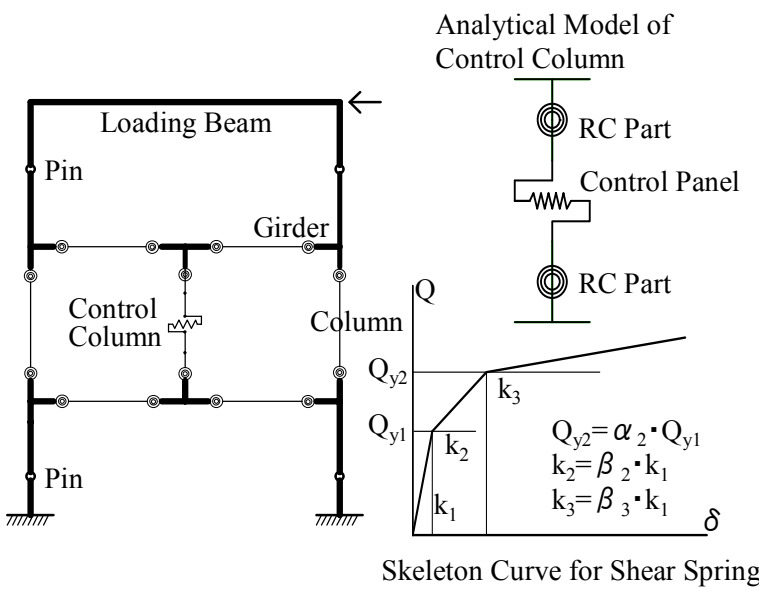

Fig. 18 Analysis model of RC frame. 
elasto-plastic characteristics of each RC member, as shown in Fig. 18. In the analysis model, the flexural deformations of columns and girders behave nonlinearly whereas the shear and axial deformations behave elastically. Exploiting the macroscopic model of the control panel that was mentioned in Chapter 3, the shear deformation of the control panel is modeled by using a shear spring while the flexural deformations at the top and bottom of the control column are modeled by using the flexural springs of the RC column. Shear panels are set for the joints between columns and girders, and between the control column and the girders.

\section{(2) Restoring force characteristics}

The Takeda model (Takeda 1970) that describes a crack point and a yield point is used for the restoring force characteristics of flexural deformations of columns and girders. A Normal Tri-linear curve model describes the restoring force characteristics of shear deformations of the control panel. The skeleton curve of the control panel is based on the shear yield point of the web plate, such as a low-yield-point steel panel as mentioned in Chapter 3. However, the low-yield-point steel panel of this specimen that has the first yielding stress of approximately $100 \mathrm{~N} / \mathrm{mm}^{2}$ does not demonstrate the exact value of a shear yield point. Therefore, the properties of the first and second yield points are referred to in the test results of the control panel itself, as shown in Table 4. The selection of property values is based on those obtained from the results at $\mathrm{Rf}=1 / 100$. In addition, the deformations of steel connection members are taken into consideration.

\section{(3) Restoring force characteristics of frame}

Figure 19 shows the comparison of restoring force characteristics between the static loading test results and the analysis model of the frame with the control column. Most of the analysis values are less than the values from test results. However, at $\mathrm{Rf}$ of $1 / 100$, the analysis values can accurately represent the values from static-loading test results. When the values of the energy absorption of the frame are compared with the values from the test results, the analysis values of the energy absorption of the frame range from $70 \%$ to $90 \%$ of the test results after the sequence of displacement at $\mathrm{Rf}=1 / 300$ (see Fig. 20). Therefore the analysis model satisfactorily expresses the characteristics of the RC frame obtained from the test results.

\section{Performance evaluation of RC frame with multiple damage fuses}

\subsection{Performance evaluation of RC frame with} multiple damage fuses by structural experiment In this chapter, the paper studies the application of a RC frame with the combination of multiple damage fuses (Fig. 1). The types of damage fuses are as follows: a stud (control column), an oil-damper brace (viscous
Table 4 Properties of skeleton curve for analysis (Control panel).

\begin{tabular}{|c|c|c|c|c|}
\hline $\begin{array}{c}\mathrm{Q}_{\mathrm{y} 1} \\
(\mathrm{kN})\end{array}$ & $\alpha_{2}$ & $\begin{array}{c}\mathrm{k}_{1} \\
(\mathrm{kN} / \mathrm{mm})\end{array}$ & $\beta_{2}$ & $\beta_{3}$ \\
\hline 57.4 & 2.5 & 267.5 & 0.4 & 0.04 \\
\hline
\end{tabular}

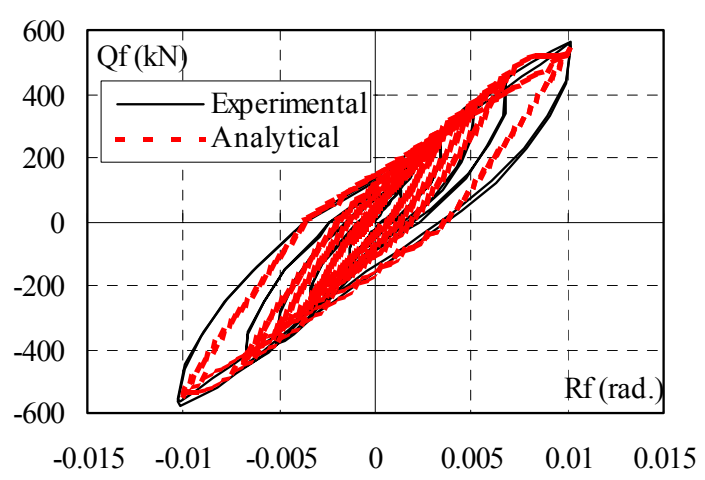

Fig. 19 Comparison of restoring force characteristics between static loading test results and analysis model of frame with control column.

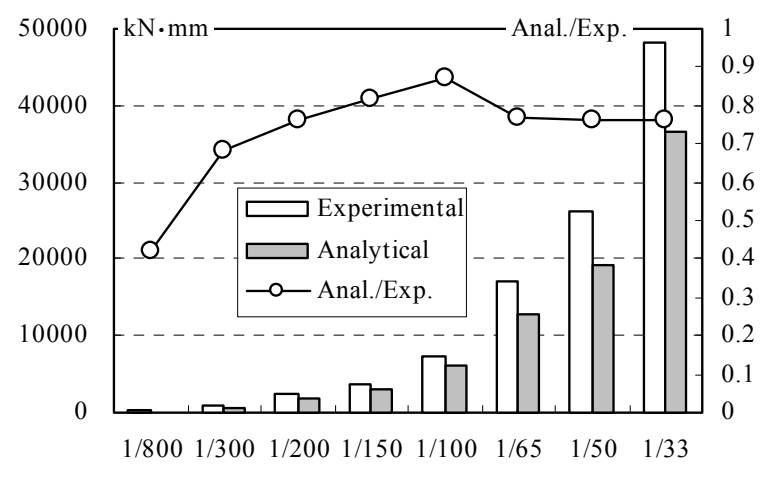

Fig. 20 Comparison of energy absorption between static loading test results and analysis model of frame with control column.

damping system) and an unbonded low-yield-point steel brace (hysteresis system); those braces will be hereinafter called control braces. More space can be effectively allocated by using the combination of the control column and control braces. Combining a control panel with a control brace (using different damping characteristics: hysteresis system and viscous damping system) can demonstrate outstanding damping effects on wide-ranging excitation. This chapter presents static and dynamic loading tests of a one-story RC frame model with damage fuses. The test results show the damping-added performance of the damage fuses on RC frames. Furthermore, the paper proposes the analysis models and the validity of the restoring force character- 
istics of its frame with the damage fuses.

\subsection{Structural experiment of RC frame with multiple damage fuses}

\subsubsection{Outline of experimental procedure}

\section{(1) Experimental procedure}

First, the dynamic loading test was performed on an RC frame with a control column and an oil-damper brace. Next, the oil damper was replaced by an unbonded brace, and the static loading test was performed. For the experimental results of a frame itself, the sizes of the specimen was identical to those mentioned in Chapter 4. Therefore, the results of testing an $\mathrm{RC}$ frame itself (frame-base test) were derived from the results in Chapter 4.

\section{(2) Test specimen}

The test specimen was a half-scale model of a one-story rigid $\mathrm{RC}$ frame that consists of columns and girders. The control column was placed in the middle of the span of its frame. The control brace was placed in an opening between the control column and a column of its frame (see Fig. 21 and Table 5). The frame was designed so that the flexural yielding of girders precedes the flexural yielding of columns. The control panel consisted of a low-yield-point steel web plate (first axial-yielding stress of $100 \mathrm{~N} / \mathrm{mm}^{2}$ ), vertical flange plates of SM490 and base plates of SM490 at the top and the bottom of the panel (see Fig. 22). The maximum damp- ing force of the oil-damper brace was approximately equivalent to the maximum strength of an unbonded brace. The properties of design characteristics (damping force-velocity curve) of the oil-damper brace are shown in Fig. 23. The core member of the unbonded brace used a low-yield-point steel plate (first axial-yielding stress of $100 \mathrm{~N} / \mathrm{mm}^{2}$ ) with $16 \mathrm{~mm}$ by $60 \mathrm{~mm}$ (thickness by width). The results of material testing are listed in Table 6.

\section{(3) Test setup and loading sequence}

First, the dynamic-loading tests were performed. Next, the oil-damper brace was replaced by an unbonded brace and the static loading test was performed. The values of Rf for dynamic loading were controlled by the

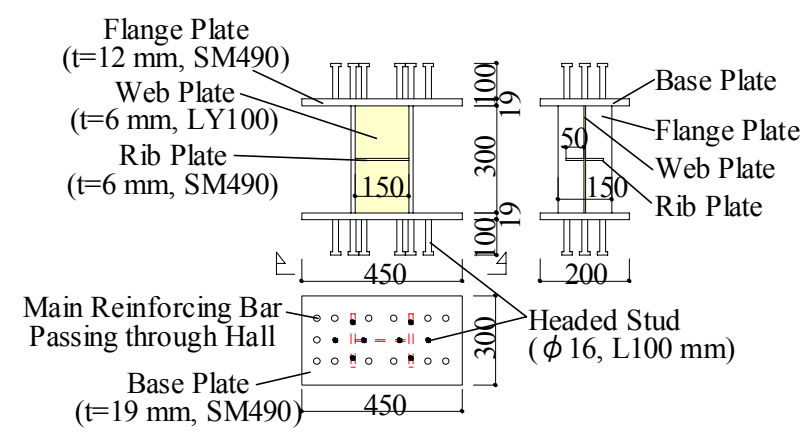

Fig. 22 Test specimen of control panel.
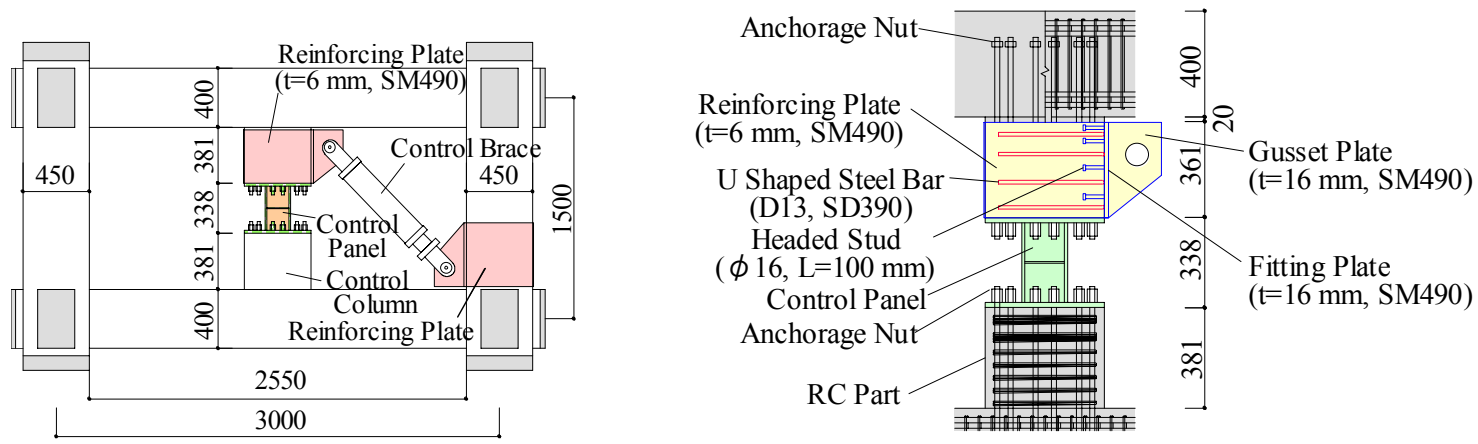

Fig. 21 Test specimen of RC frame with multiple damage fuses.

Table 5 Specification for test specimen of RC frame with multiple damage fuses.

\begin{tabular}{|c|c|c|c|c|}
\hline & $\begin{array}{c}\mathrm{B} \times \mathrm{D} \\
(\mathrm{mm})\end{array}$ & $\begin{array}{c}\mathrm{Fc} \\
\left(\mathrm{N} / \mathrm{mm}^{2}\right)\end{array}$ & $\begin{array}{c}\text { Main Rein- } \\
\text { forcing Bar }\end{array}$ & $\begin{array}{c}\text { Reinforcing } \\
\text { Bar }\end{array}$ \\
\hline Column & $450 \times 450$ & 45 & $\begin{array}{c}16-\mathrm{D} 22^{* 1} \\
(\mathrm{SD} 490)\end{array}$ & $\begin{array}{c}4-\phi 6 @ 50 \\
(\mathrm{USD} 685)\end{array}$ \\
\hline Girder & $200 \times 400$ & 35 & $\begin{array}{c}4+2-\mathrm{D} 19 \\
(\mathrm{SD} 490)\end{array}$ & $\begin{array}{c}4-\phi 6 @ 40 \\
(\mathrm{USD} 685)\end{array}$ \\
\hline Control Column & $200 \times 450$ & 35 & $\begin{array}{c}14-\mathrm{D} 19 \\
(\mathrm{SD} 490)\end{array}$ & $\begin{array}{c}4-\mathrm{D} 66^{* 2} \\
(\mathrm{SD} 295 \mathrm{~A}) \\
2-\mathrm{D} 6 \\
(\mathrm{SD} 295 \mathrm{~A})\end{array}$ \\
\hline
\end{tabular}

*1 Main Reinforcing Bar of Column Reinforcing Plate Part: 20-D22

*2 Reinforcing Bar of Control Column Part: 4-D6 
Table 6 Results of material testing (RC frame with multiple damage fuses).

\begin{tabular}{|c|c|c|c|}
\hline $\begin{array}{c}\text { Steel Bar and Steel Plate } \\
\text { (Material) }\end{array}$ & $\begin{array}{c}\text { Young's Modulus } \\
\times 10^{5} \mathrm{~N} / \mathrm{mm}^{2}\end{array}$ & $\begin{array}{c}\text { Yield Strength } \\
\mathrm{N} / \mathrm{mm}^{2}\end{array}$ & $\begin{array}{c}\text { Tensile Strength } \\
\mathrm{N} / \mathrm{mm}^{2}\end{array}$ \\
\hline D22 (SD490) & 1.93 & 509 & 685 \\
\hline D19 (SD490) & 1.92 & 523 & 666 \\
\hline$\phi 6$ (USD685) & 1.80 & 701 & 846 \\
\hline D6 (SD295A) & 1.71 & 330 & 469 \\
\hline PL4.5 (LY100) & 1.69 & 97 & 248 \\
\hline \hline Concrete & $\begin{array}{c}\text { Secant Modulus } \\
\times 10^{5} \mathrm{~N} / \mathrm{mm}^{2}\end{array}$ & $\begin{array}{c}\text { Compressive Strength } \\
\mathrm{N} / \mathrm{mm}^{2}\end{array}$ & $\begin{array}{c}\text { Cleavage Strength } \\
\mathrm{N} / \mathrm{mm}^{2}\end{array}$ \\
\hline $\begin{array}{c}\text { Girder } \\
\text { Control Column }\end{array}$ & 0.26 & 31 & 2.35 \\
\hline Column & 0.35 & 55 & 4.56 \\
\hline
\end{tabular}

Note:For SM490 steel plates, refer to Table 3.

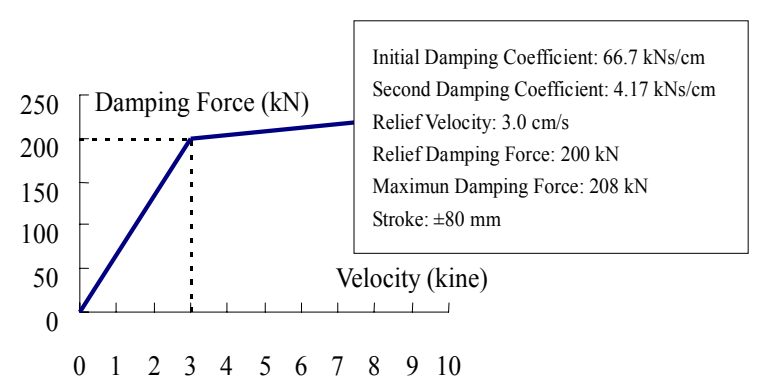

Fig. 23 Design properties of oil damper.

horizontal displacements of a loading beam (Fig. 24). The dynamic-loading test used two types of natural periods, 2 and 4 seconds, respectively, in consideration of the natural periods of high-rise RC structures. The target drift angles of $1 / 800$ and $1 / 300$ were chosen for dynamic loading. The target drift angle of 1/300 indicates the drift angle caused by earthquakes that rarely occur. The loading histories for dynamic and static tests are shown in Fig. 25.

\subsubsection{Results of dynamic loading test}

\section{(1) Experimental progress}

A relatively small number of cracks developed in the columns. The maximum residual crack width was approximately $0.06 \mathrm{~mm}$ at the end of girders while most crack widths were smaller than $0.04 \mathrm{~mm}$. The stresses of longitudinal reinforcing bars of both girders and columns were still within the elastic limit after the test.

\section{(2) Load-lateral drift angle relationships}

The load-displacement relationships for dynamic loading are shown in Fig. 26 (Target $\mathrm{Rf}=1 / 300$ rad.). Prior to the first yielding of reinforcing bars, the combination of damage fuses can upgrade the damping performance of an RC frame.

\section{(3) Amount of energy absorption}

The comparison (the test result and frame-based test) of the amounts of energy absorption is shown in Fig. 27.

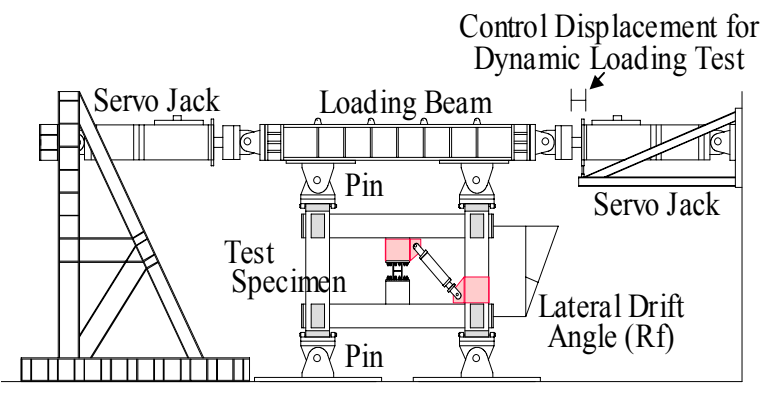

Fig. 24 Test setup.

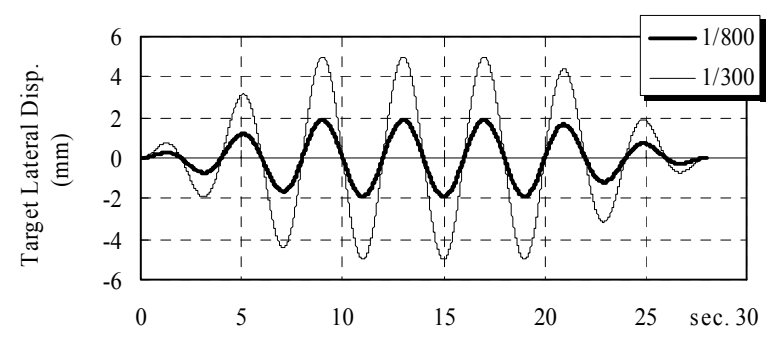

(a) Dynamic test (Control column and oil-damper brace)

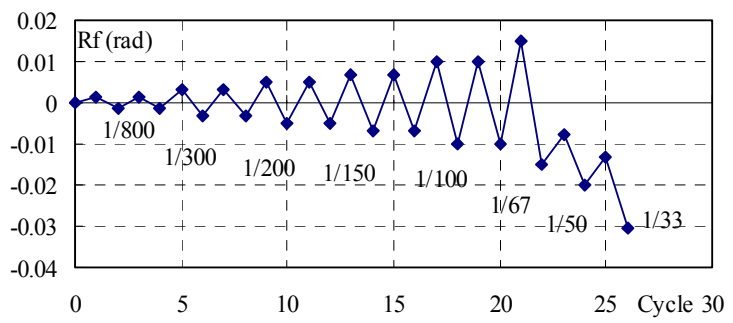

(b) Static test (Control column and unbonded brace)

Fig. 25 Loading histories.

The amounts of energy absorption were calculated by averaging the energy absorption values of three sequential loops. The results of an $\mathrm{RC}$ frame with a control-column mentioned in Chapter 4 are also shown. These results show that the installation of damage fuses can greatly increase the amount of energy absorption. (Damage fuses dissipate the energy created by earthquake excitations.) 
The equivalent viscous damping coefficient of the dynamic loading test result is approximately 0.16 (at $\mathrm{Rf}$ of 1/298), whereas the coefficient of the frame itself is approximately 0.02 (at $\mathrm{Rf}$ of $1 / 230$ ). Therefore, the installation of damage fuses can greatly improve the effect of damping on an $\mathrm{RC}$ frame.

\subsubsection{Results of static loading test}

\section{(1) Experimental progress}

Figure 28 shows the crack patterns after testing. The maximum residual crack width was approximately 0.06 $\mathrm{mm}$ when $\mathrm{Rf}$ reached $1 / 150$. Some of the reinforcing bars of girders started to yield when Rf reached $1 / 100$. When $\mathrm{Rf}$ reached $1 / 67$, all longitudinal reinforcing bars in girders yield at the maximum residual crack width of $0.15 \mathrm{~mm}$. The flexural cracks of columns, meanwhile, started to develop when $\mathrm{Rf}$ reached $1 / 200$. The numbers of flexural cracks of columns increased with $\mathrm{Rf}$, whereas most of the residual cracks of columns were closed after testing. The frame demonstrated that the flexural yielding of girders precedes the flexural yielding of columns. The web plate of the control panel deformed out of plane of the web plate when $\mathrm{Rf}$ reached $1 / 150$ for the control-column test, whereas the web plate deformed out of plane when $\mathrm{Rf}$ reached $1 / 100$ for the control-column and control-brace test. The out-of-plane deformations increased with $\mathrm{Rf}$, whereas no tear in the web plate developed at $\mathrm{Rf}$ of $1 / 33$. The out-of-plane deformation started to develop adjacent to the pinned joint of the unbonded brace after the sequential loading of $\operatorname{Rf}$ of $1 / 100$. After the sequential loading of $\mathrm{Rf}$ of $1 / 67$, the out-of-plane deformations adjacent to the pinned joints became marked. Therefore, the direction of loading is set to move only in the direction in which the unbonded brace shows the characteristics of tensile stress.

\section{(2) Load-lateral drift angle relationships}

Figure 29 shows the load-lateral drift angle relationships of the static loading tests. Prior to the flexural yielding of the longitudinal reinforcing bars of the girders at $\mathrm{Rf}$ of $1 / 67$, the restoring force characteristics demonstrated a great capacity for energy dissipation showing spindle-shaped loops because of the yielding of the damage fuses. No sign of strength degradation was seen when $\mathrm{Rf}$ reached only $1 / 33$ in the above-mentioned direction.

\subsection{Analysis model of RC frame with multiple damage fuses}

\section{(1) Analysis model}

The analysis model of the frame is based on the elasto-plastic characteristics of each RC member, as shown in Fig. 30. In the analysis model, the flexural deformations of columns and girders behave nonlinearly whereas the shear and axial deformations behave elastically. As in the macroscopic analysis model that is mentioned in Chapter 3, the shear deformation of the control

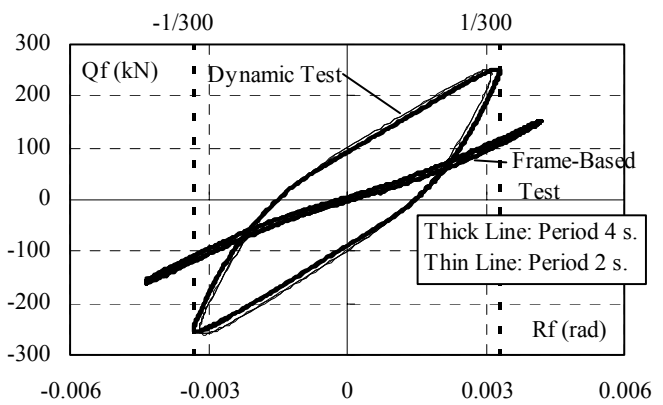

Fig. 26 Load-lateral drift angle relationships (Target $\mathrm{Rf}=1 / 300$ rad.).

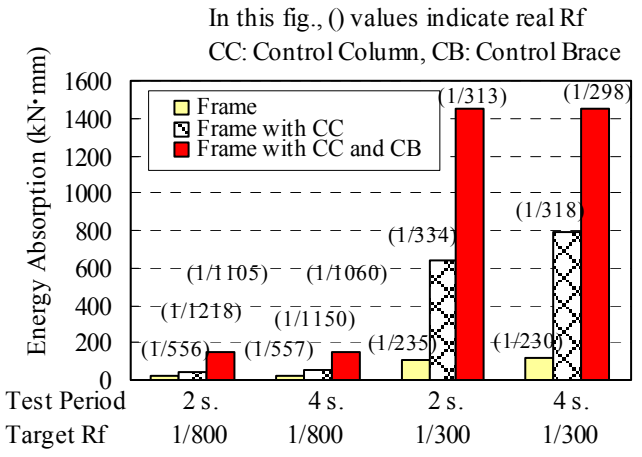

Fig. 27 Comparison of energy absorption.

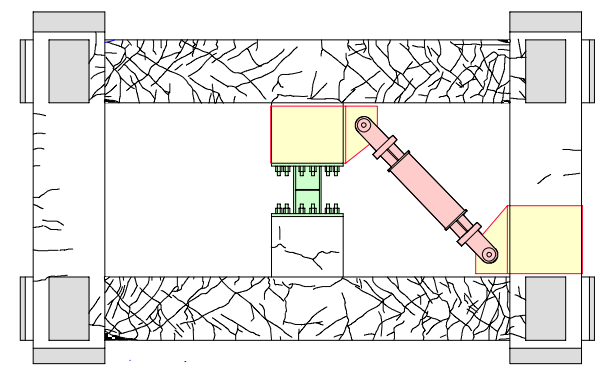

Fig. 28 Crack patterns after testing.

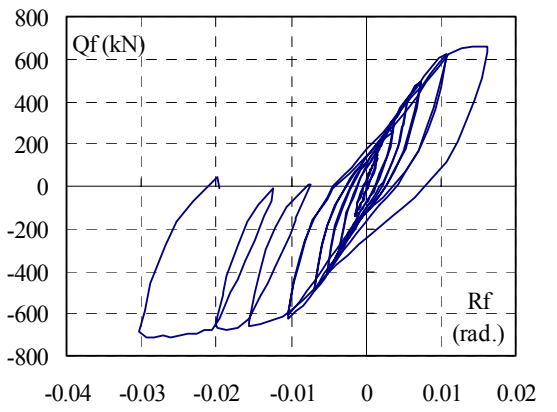

Fig. 29 Load-lateral drift angle relationships (Static loading test). 


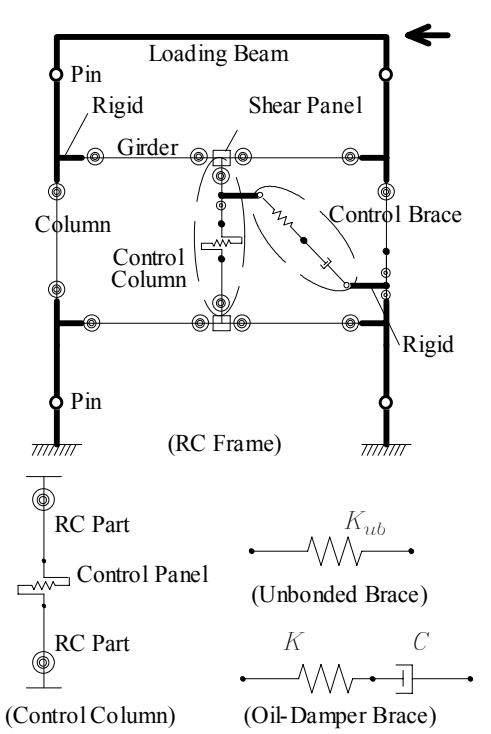

Fig. 30 Analysis model of RC frame and damage fuses.

panel is modeled by using a shear spring while the flexural deformations of the top and bottom of the control column are modeled by using the flexural springs of the $\mathrm{RC}$ column. A Maxwell model with a linear axial spring of the brace describes the analysis model of an oil-damper brace whereas a bi-linear axial spring describes the analysis model of an unbonded brace. Pinned joints at each end, where steel plates reinforce the top of an RC stud and the bottom of a column, connect each of the braces. Rigid zones are set for the column-girder joints while shear panels are set for the joints between the control-column and the girders. Another rigid zone is also placed in each end of the control brace in order to consider the eccentricity of the brace that acts on the columns.

\section{(2) Restoring force characteristics}

The Takeda model (Takeda 1970) that describes a crack point and a yield point is used for the restoring force characteristics of flexural deformations of columns and girders. A bi-linear curve model that exhibits a yield point describes the analysis model of the only column that is strengthened by the reinforcing steel plates. A Normal Tri-linear curve model describes the restoring force characteristics of shear deformations of the control panel. The low-yield-point of the control panel that has the first yielding stress of approximately $100 \mathrm{~N} / \mathrm{mm}^{2}$ does not demonstrate the exact value of the shear yield point. Therefore, the properties of a first and second yield points are referred to in the test results of the control panel itself, as shown in Table 7. The criterion point of the low-yield-point panel is chosen to be the $\mathrm{Rf}$ of 1/100. And finally, a Normal Tri-linear curve of an axle spring describes the restoring force of an unbonded brace (see Table 7).

\section{(3) Restoring force characteristics of frame}

The analysis model of restoring force characteristics of an RC frame with multiple damage fuses is compared with the test results. First, the analysis model of the frame with the control-column and the oil-damper brace (natural period of 4 seconds at Rf of 1/298) is compared with the dynamic loading test results for the same. The analysis value of the amount of energy absorption of the frame is approximately $95 \%$ of the test result while the analysis value of the equivalent viscous damping coefficient is approximately $93 \%$ of the test result.

Next, the analysis model of the frame with the control column and the unbonded brace was compared with the static loading test results of the same (Fig. 31). The analysis values of the energy absorption of the frame are somewhat larger than the test results as the analysis values range from $101 \%$ to $131 \%$ of the test results under the displacements ranging from $\mathrm{Rf}=1 / 300$ to $\mathrm{Rf}=1 / 200$. However, the analysis values range from 92

Table 7 Restoring force characteristics of damage fuses.

(a) Control panel and unbonded brace

\begin{tabular}{|c|c|c|}
\hline & $\begin{array}{c}\text { Control } \\
\text { Panel }\end{array}$ & $\begin{array}{c}\text { Unbonded } \\
\text { Brace }\end{array}$ \\
\hline $\begin{array}{c}\text { Initial Stiffness } \\
(\mathrm{kN} / \mathrm{mm})\end{array}$ & 99.0 & 397.8 \\
\hline $\begin{array}{c}\text { Initial Bending Point } \\
\text { Load (kN) }\end{array}$ & 59.4 & 96.0 \\
\hline $\begin{array}{c}\text { Second Bending } \\
\text { Point Load (kN) }\end{array}$ & 153.2 & 192.0 \\
\hline $\begin{array}{c}\text { Second Gradient } \\
\text { Ratio }\end{array}$ & 0.063 & 0.2 \\
\hline Third Gradient Ratio & 0.02 & 0.001 \\
\hline
\end{tabular}

(b) Oil-damper brace

\begin{tabular}{|c|c|}
\hline Spring Stiffness $(\mathrm{kN} / \mathrm{mm})$ & 137 \\
\hline $\begin{array}{c}\text { Initial Damping Coefficient } \\
(\mathrm{kN} \cdot \mathrm{s} / \mathrm{mm})\end{array}$ & 667 \\
\hline $\begin{array}{c}\text { Second Damping Coefficient } \\
(\mathrm{kN} \cdot \mathrm{s} / \mathrm{mm})\end{array}$ & 41.7 \\
\hline $\begin{array}{c}\text { Initial Bending Point Velocity } \\
(\mathrm{mm} / \mathrm{s})\end{array}$ & 30 \\
\hline $\begin{array}{c}\text { Initial Bending Point Damping } \\
\text { Force }(\mathrm{kN})\end{array}$ & 200 \\
\hline
\end{tabular}

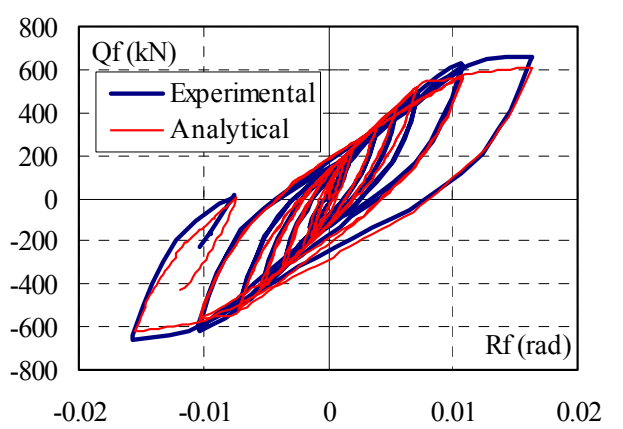

Fig. 31 Comparison of restoring force characteristics between static loading test results and analysis model of frame with control column and unbonded brace. 
to $109 \%$ of the test results under the displacements ranging from $\mathrm{Rf}=1 / 150$ to $\mathrm{Rf}=1 / 100$. Therefore the analysis model appropriately expresses the characteristics of the RC frame obtained from the test results.

\section{Performance evaluation of super high-strength RC frame with control column}

\subsection{Performance evaluation of super high-strength RC frame with control columns by structural experiment}

This chapter examines the application of a super high-strength RC frame with control columns. Reactive Powder Concrete (RPC) with compressive strength of $200 \mathrm{~N} / \mathrm{mm}^{2}$ mixed with steel fibers was used for the frame (RPC frame). RPC was a combined material consisting of reactive powder such as cement, silica fume and fine aggregates. By placing control-devices of high damping quality in an RPC frame mixed with steel fibers, the evaluation aims to achieve the realization of damage-controllable high-rise RC buildings during disastrous earthquakes. The control devices that were chosen consisted of the control-column type that contains a low-yield-point steel panel whose deformation depends on its relative angle drift (hysteresis system). The oil-damper type will be reported in a separate paper.

This chapter presents the static loading tests of a three-story RPC frame of model specimen with control columns. First, the behaviors of an RPC frame and the performance of added damping (control columns) is stated. Next, the analysis model of the RPC frame with control-columns is formulated, and the model is evaluated by comparing the model with the test results.

\subsection{Structural experiment of super high-strength RC frame with control columns}

\subsubsection{Outline of experimental procedure}

(1) Experimental procedure

Prior to installing the control panels, the RPC frame itself was tested to evaluate the restoring force characteristics before the flexural yielding of reinforcing bars (frame-based test). Then, the control panels were installed in the control columns, and the static loading test was conducted on the RPC frame to evaluate the performance of added damping of control columns before the flexural yielding of reinforcing bars and also the restoring force characteristics under large deflections.

(2) Test specimen (see Fig. 32)

The RPC frame was designed so that the flexural yielding of girders precedes the flexural yielding of columns. The USD685 material was used for the longitudinal reinforcing bars of its columns and girders. Steel bars (SBPD 1275/1420) for prestressed concrete and the USD685 material were used for the hoops in the columns and the stirrups in the girders, respectively. Precast concrete columns and girders were separately manufactured. A shear-key was placed in each connection face. The specifications of the test specimens are listed in Table 8. The control panel consisted of a
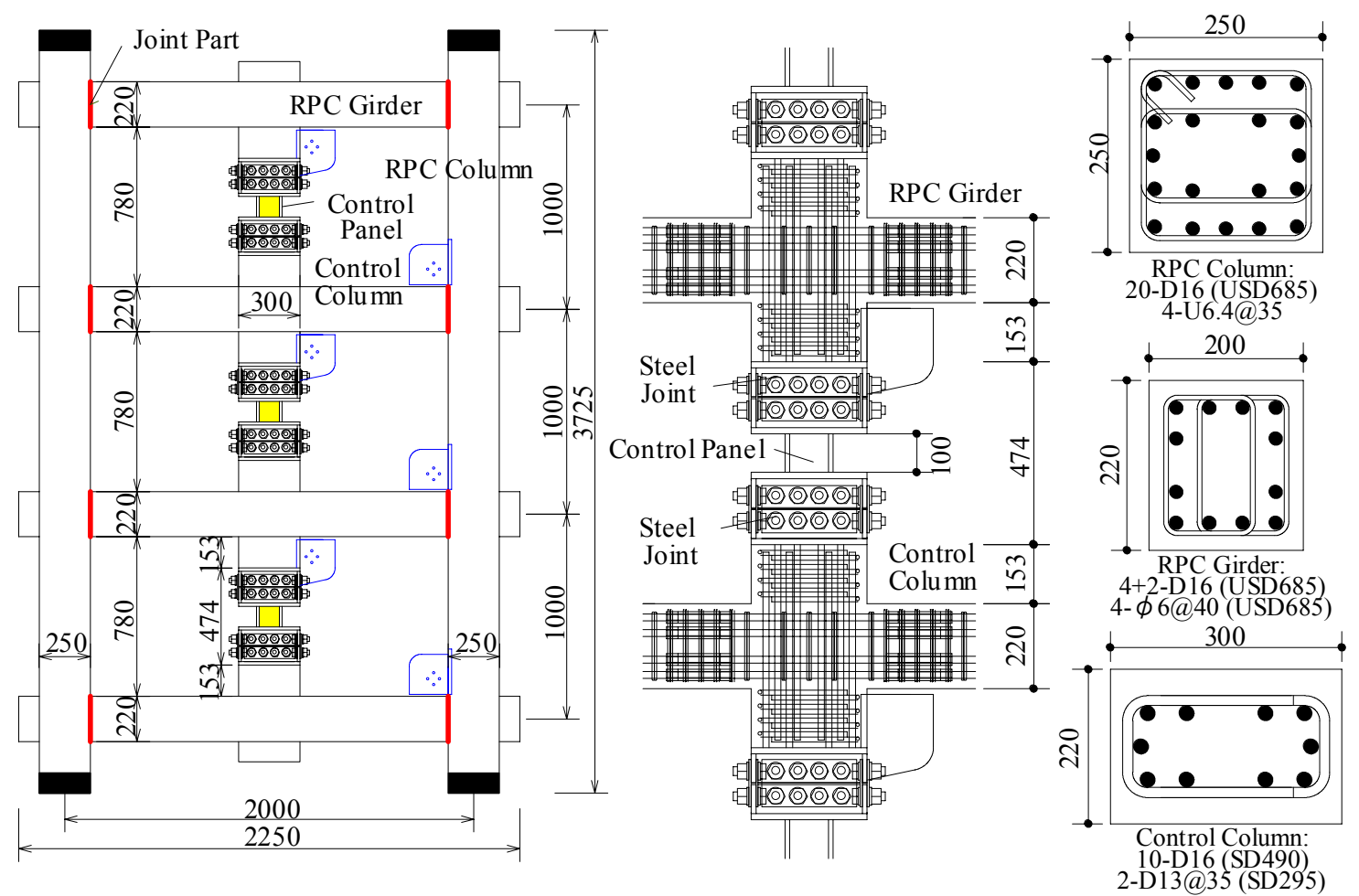

Fig. 32 Test specimen for RPC frame with damage fuse. 
low-yield-point steel web plate (first axial-yielding stress of $100 \mathrm{~N} / \mathrm{mm}^{2}$ ), vertical flange plates of SM490 and base plates of SM490 at the top and the bottom of the panel (see Fig. 33). RC members and control columns were unified by control-column re-bars, which were welded to steel connections.

The properties of RPC members are listed in Table 9. Steam curing was used for the specimens after pouring the RPC. The temperature was increased by $15^{\circ} \mathrm{C}$ per hour until it reached $90^{\circ} \mathrm{C}$. Then, a temperature of $90^{\circ} \mathrm{C}$ was maintained for 48 hours, and the temperature was naturally lowered for 24 hours. The results of material testing are listed in Table $\mathbf{1 0 .}$

\section{(3) Test setup and loading sequence}

The test setup shows that a pin support at one end of a loading beam above the top of a column is loaded by an actuator (Fig. 34). The loading sequence is controlled by the drift angles of the second story (Rf) since it is least influenced by the boundary condition of the actuator (Fig. 35). Incidentally, no axial force is loaded for the specimen because the frames in the middle portion are designed so that the flexural yielding of girders pre-

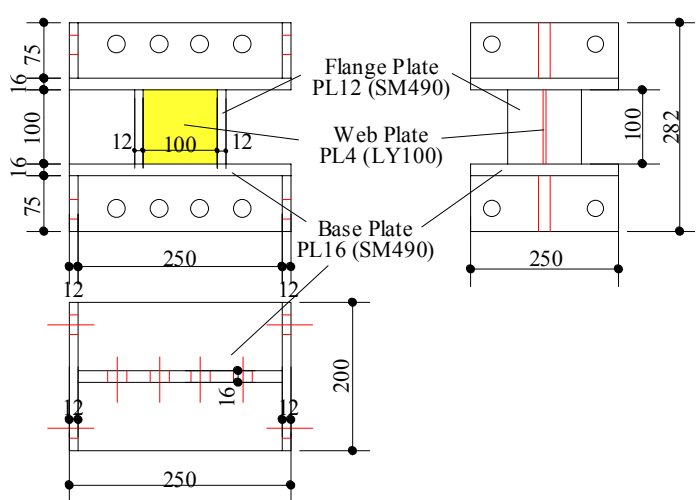

Fig. 33 Test specimen for control panel.

Table 8 Specification of test specimen for RPC frame.

\begin{tabular}{|c|c|c|c|c|}
\hline & $\begin{array}{c}\mathrm{B} \times \mathrm{D} \\
(\mathrm{mm})\end{array}$ & $\begin{array}{c}\mathrm{Fc} \\
\left(\mathrm{N} / \mathrm{mm}^{2}\right)\end{array}$ & $\begin{array}{c}\text { Main Rein- } \\
\text { forcing Bar }\end{array}$ & Reinforcing Bar \\
\hline Column & $\begin{array}{c}250 \\
\times\end{array}$ & 200 & $\begin{array}{c}20-\mathrm{D} 16 \\
(\mathrm{USD} 685)\end{array}$ & $\begin{array}{c}4-\mathrm{U} 6.4 @ 35 \\
(\mathrm{SBPD} 1275 / 1420)\end{array}$ \\
\hline Girder & $\begin{array}{c}200 \\
\times\end{array}$ & 200 & $\begin{array}{c}4+2-D 16 \\
(\mathrm{USD} 685)\end{array}$ & $\begin{array}{c}4-\phi 6 @ 40 \\
(\mathrm{USD} 685)\end{array}$ \\
\hline $\begin{array}{c}\text { Control } \\
\text { Column }\end{array}$ & $\begin{array}{c}200 \\
\times\end{array}$ & 200 & $\begin{array}{c}10-\mathrm{D} 16 \\
(\mathrm{SD} 490)\end{array}$ & $\begin{array}{c}2-\mathrm{D} 13 @ 35 \\
\text { (SD295A) }\end{array}$ \\
\hline
\end{tabular}

Table 9 Mix proportioning for RPC material (unit: $\mathrm{kg} / \mathrm{m}^{3}$ ).

\begin{tabular}{|c|c|c|}
\hline Water*) $^{*}$ & RPC Pre-Mix & $\begin{array}{c}\text { Steel Fiber } \\
\phi 0.2 \times 15 \mathrm{~mm} \\
(2 \mathrm{vol} \%)\end{array}$ \\
\hline 180 & 2254 & 157 \\
\hline
\end{tabular}

*) : Includes High-Range Water Reducing Agent cedes the flexural yielding of columns.

\subsubsection{Experimental result of static loading}

(1) Experimental progress of frame-based test

A relatively small number of cracks developed in the members. However, a few cracks formed in the connections. The longitudinal bars in both columns and girders were within the limit of elasticity.

\section{(2) Experimental progress}

The crack patterns of the frame of the second story after testing are shown in Fig. 36. Flexural cracks start to develop in girders when $\mathrm{Rf}$ reaches $1 / 250$. Flexural-shear cracks in girders and flexural cracks in columns occurred when $\mathrm{Rf}$ reached 1/100. The maximum residual crack width in girders was $0.04 \mathrm{~mm}$ when $\mathrm{Rf}$ reached $1 / 100$ whereas the other residual cracks were less than $0.04 \mathrm{~mm}$. When Rf reached $1 / 75$, shear cracks occurred in girders and some of the reinforcing bars of girders started to yield. After testing, most of the residual cracks in columns were less than $0.04 \mathrm{~mm}$. Gaps in the connection between the column and girder (column-girder connection) dominated the deformations at the end of the girder. The frame demonstrated that the flexural yielding of girders precedes the flexural yielding of columns. The web plate of the control panel deforms out of the plane of the web plate when Rf reaches $1 / 100$. No conspicuous sign of strength degradation was seen until the weld cracking of the vertical flange caused strength degradation when $\mathrm{Rf}$ reached $1 / 50$ in the negatively loading direction of the second cycle.

\section{(3) Load-lateral drift angle relationships}

Figure 37 shows the load-lateral drift angle (drift angle of second story) relationships of the static loading tests. In the range of small displacements, the frame-based test of the RPC frame itself shows elastic regions. On the other hand, the test of the RPC frame with control panel shows that prior to the flexural yielding of longitudinal reinforcing bars of girders at $\mathrm{Rf}$ of $1 / 75$, the restoring force characteristics demonstrate a great capacity for energy dissipation showing spindle-shaped loops because of the yielding of the control panel. No conspicuous sign of strength degradation was seen until Rf

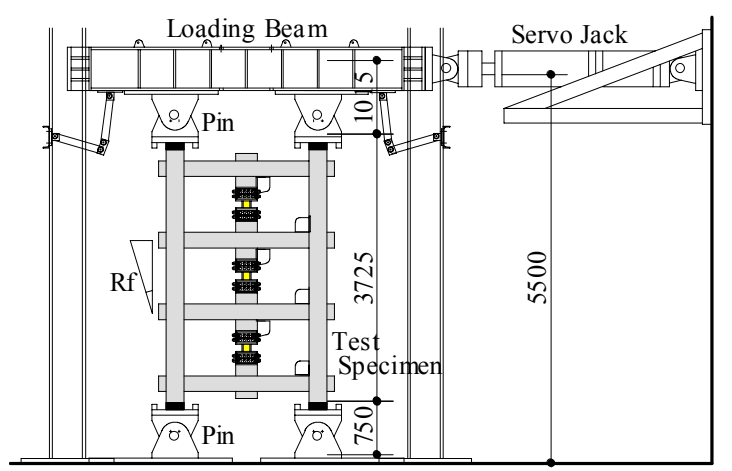

Fig. 34 Test setup for RPC frame test. 
Table 10 Results of material testing.

\begin{tabular}{|c|c|c|c|}
\hline $\begin{array}{c}\text { Steel Bar and Steel Plate } \\
\text { (Material) }\end{array}$ & $\begin{array}{l}\text { Young's Modulus } \\
\quad \times 10^{5} \mathrm{~N} / \mathrm{mm}^{2}\end{array}$ & $\begin{array}{l}\text { Yield Strength } \\
\qquad \mathrm{N} / \mathrm{mm}^{2}\end{array}$ & $\begin{array}{l}\text { Tensile Strength } \\
\mathrm{N} / \mathrm{mm}^{2}\end{array}$ \\
\hline D16 (USD685) & 1.909 & 750 & 959 \\
\hline D16 (SD490) & 1.905 & 546 & 752 \\
\hline D16 (SD390) & 1.877 & 474 & 677 \\
\hline $\begin{array}{c}\text { U6.4 } \\
\text { (SBPD1275/1420) }\end{array}$ & 1.959 & 1369 & 1403 \\
\hline$\phi 6($ USD685) & 1.910 & 742 & 933 \\
\hline PL4 (LY100) & 1.914 & 116 & 250 \\
\hline PL12 (SM490) & 2.067 & 364 & 529 \\
\hline PL16 (SM490) & 2.082 & 363 & 539 \\
\hline $\mathrm{RPC}$ & $\begin{array}{l}\text { Secant Modulus } \\
\left(\times 10^{5} \mathrm{~N} / \mathrm{mm}^{2}\right)\end{array}$ & \multicolumn{2}{|c|}{$\begin{array}{c}\text { Compressive Strength } \\
\left(\mathrm{N} / \mathrm{mm}^{2}\right)\end{array}$} \\
\hline $\begin{array}{c}\text { Girder, } \\
\text { Control Column }\end{array}$ & 0.533 & \multicolumn{2}{|c|}{225} \\
\hline Column & 0.555 & \multicolumn{2}{|r|}{235} \\
\hline
\end{tabular}

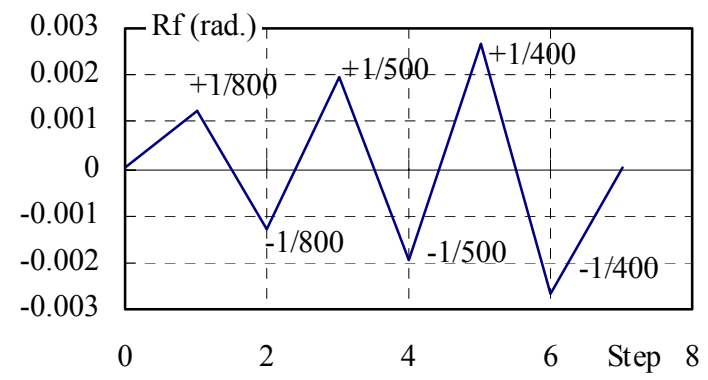

(a) Basic test (RPC frame only)

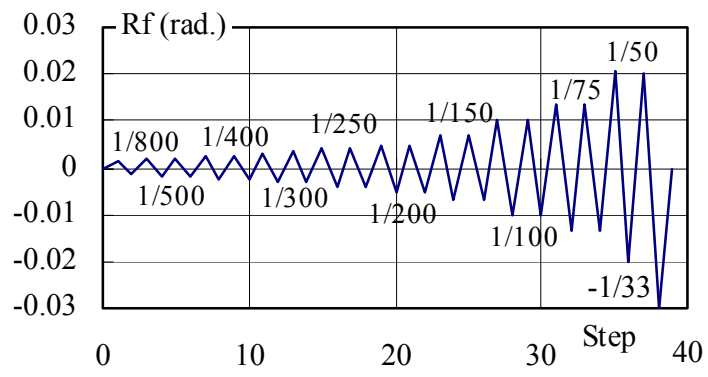

(b) Static test (with control column)

Fig. 35 Loading histories for RPC frame test.

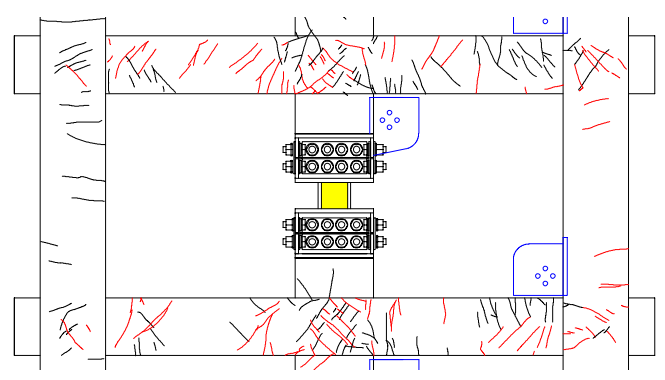

Fig. 36 Crack patterns after test.

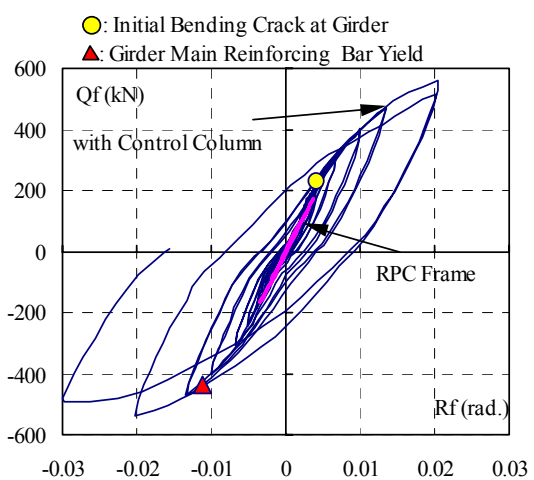

Fig. 37 Load-lateral drift angle ( $2^{\text {nd }}$ story) relationships. of $1 / 33$ in the negative loading direction.
(4) Amount of energy absorption

A comparison (static loading test of RPC frame with control columns and frame-based test) of the amounts of energy absorption until the drift angle reaches $1 / 400$ is shown in Fig. 38. It shows that installing the control columns can greatly increase the amount of energy absorption prior to the flexural yielding of longitudinal reinforcing bars. At $\mathrm{Rf}$ of $1 / 400$, the equivalent viscous damping coefficient of the RPC frame with the control column is 0.36 , whereas the coefficient of the frame itself is approximately 0.03 . Therefore, installing the control columns can greatly improve the effect of damping on the RPC frame.

\subsection{Analysis model of super high-strength RC frame with control columns}

(1) Analysis model

The analysis model of the frame is based on the elasto-plastic characteristics of each member, as shown in Fig. 39. The models mentioned in Chapter 5 are used for columns, girders and control columns.

(2) Restoring force characteristics

The Takeda model (Takeda 1970) that describes a crack 
point and a yield point is used for the restoring force characteristics of flexural deformations of columns and girders $(\gamma=0.4)$. It can be noted that it is difficult to model the rigidity of an RPC frame as a non-linear model such as a RC model in general since the RPC frame shows the small sizes of residual cracks, and also a gap in the connection between the column and girder (column-girder connection) dominates the deformations at the end of the girder. Therefore, the second rigidity refers to the test result of the frame-based test. A Normal Tri-linear curve model describes the restoring force characteristics of shear deformations of the control panel. The restoring force characteristics of control panels are listed in Table 11, similarly to in Chapter 5.

\section{(3) Restoring force characteristics of frame}

The analysis model of restoring force characteristics of the RPC frame (second story) with control columns is compared with the test results (Fig. 40). The analysis model appropriately expresses the characteristics of the RPC frame obtained from the test results. The analysis value of the amount of energy absorption of the frame is approximately $80 \%$ of the test result at $\mathrm{Rf}$ of $1 / 50$ whereas under large displacement regions, the analysis values are somewhat inferior to the values of the test results.

The analysis model cannot fully express the non-linear behavior of the RPC frame such as the deformations of the column-girder connection. The authors hope to report the testing of RPC members and frames in order to quantitatively evaluate the non-linear behavior of the RPC frame in future studies.

\section{Damage control by damage fuses}

\subsection{Controlling seismic response displace- ments by damage fuses}

Seismic response analyses were performed on high-rise $\mathrm{RC}$ condominiums to study the displacement-reduction effects of installing control devices. Three types of building height ranging from $120 \mathrm{~m}$ to $180 \mathrm{~m}$ were chosen as case studies.

\section{(1) Frame types and control devices}

Three different types of RC frames, 36-story, 45-story and 54-story high-rise RC condominiums were used for analyses. Control columns of low-yield-point steel panel and oil-dampers were selected as damage fuses.

\section{(2) Analysis model}

Equivalent flexural and shear springs were substituted to RC frames for the simulation (flexural spring: elastic, shear spring: Takeda model). The energy dissipation of frames was instantaneously rigidity dependent. The damping coefficient of frames was chosen as h1 of 3\%. For the case studies, the proposed earthquake motion through engineering bedrock (Center-wave 1996) was used as the earthquake input. Flexural and shear springs

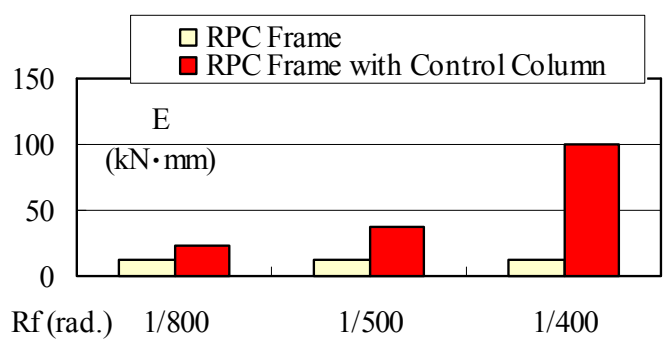

Fig. 38 Comparison of energy absorption for RPC frame test.

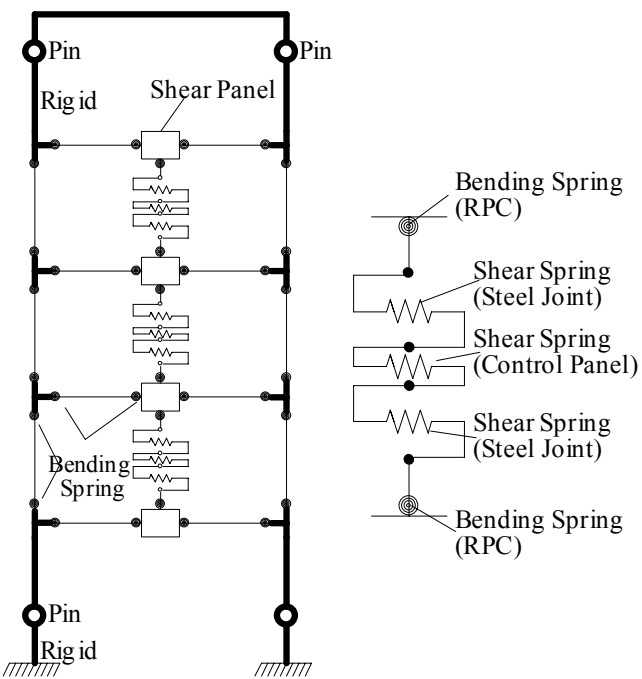

Fig. 39 Analysis model for RPC frame with damage fuse.

Table 11 Restoring force characteristics for control panel.

\begin{tabular}{|c|c|}
\hline & Control Panel \\
\hline Initial Stiffness (kN/mm) & 198.0 \\
\hline $\begin{array}{c}\text { Initial Bending } \\
\text { Point Load (kN) }\end{array}$ & 56.03 \\
\hline $\begin{array}{c}\text { Second Bending } \\
\text { Point Load (kN) }\end{array}$ & 147.1 \\
\hline Second Gradient Ratio & 0.053 \\
\hline Third Gradient Ratio & 0.01 \\
\hline
\end{tabular}

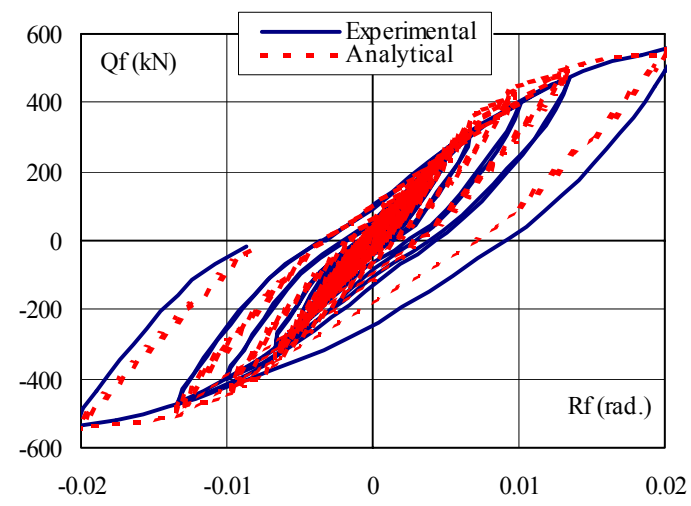

Fig. 40 Comparison of restoring force characteristics (2nd Story) between experimental test results and analysis model. 

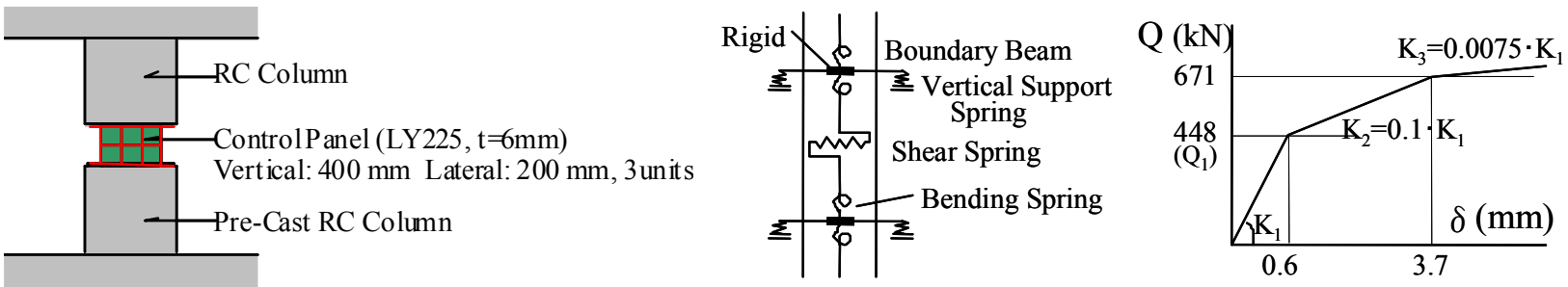

Fig. 41 Analysis model of control column.

with boundary girders were substituted to control columns, as shown in Fig. 41 (flexural spring: Takeda model, shear spring: Normal Tri-linear). The Maxwell model was chosen for modeling the oil-dampers (see Fig. 42).

\section{(3) Analysis method}

The response analyses were performed on RC frames for various numbers of control columns, and on RC frames without damping system for various damping coefficients, in order to study the displacement reduction effects of installing control devices as compared to no-damping systems. Incidentally, the system of control column that was chosen for the analyses is different from that in practical use.

\subsubsection{Damage fuses}

\section{(1) Placement of damage fuses}

From the viewpoint of structural planning, the types of damage control systems and the numbers of damage fuses were defined as the parameters (Table 12). Furthermore, a combined (Dual) system using the same numbers for both control columns (DC) and oil dampers (OIL) are also studied.

\section{(2) Added deflections through girder to con-} trol-column joint

The control column model takes added deflections of boundary girders into consideration. Oil dampers are placed horizontally within the height of relative story (not brace type). The oil damper model disregards added deflections of connecting members.

\subsection{Deflection control during earthquake by damage fuses}

\subsubsection{Results of seismic response analyses}

(1) Comparisons of control devices

The damping force increment $(\Delta \mathrm{Q})$ of DC tends to increase in large displacement regions. On the other hand, $\Delta \mathrm{Q}$ of OIL tends to increase in large velocity regions.

\section{(2) Story drift angle}

Comparing the story drift angles of each case, the greater the number of damage fuses that are installed, the greater the reduction in story drift angles although some portions of stories exhibit no reduction effect (Fig.
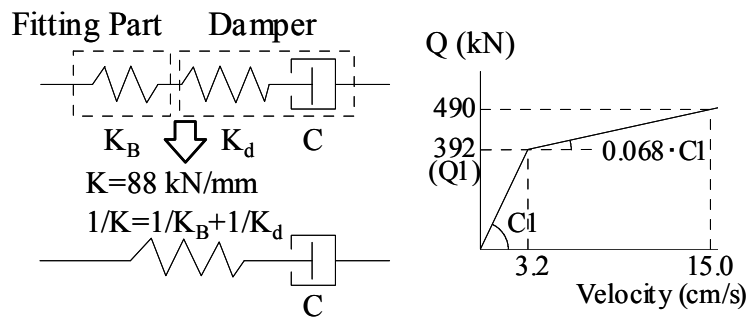

Fig. 42 Analysis model of oil-damper.

Table 12 Analysis cases with damage fuses.

\begin{tabular}{|c|c|c|c|c|c|c|}
\hline \multirow{2}{*}{$\begin{array}{l}\text { Target } \\
\text { Building }\end{array}$} & \multicolumn{2}{|c|}{$\begin{array}{c}\text { Control Column } \\
\text { (DC) }\end{array}$} & \multicolumn{2}{|c|}{ Oil-Damper (OIL) } & \multicolumn{2}{|c|}{$\begin{array}{c}\text { Combination } \\
\text { (Dual }=\mathrm{DC}+\mathrm{OIL})\end{array}$} \\
\hline & \begin{tabular}{|l|} 
Quan- \\
tity
\end{tabular} & Case & $\begin{array}{c}\text { Quan- } \\
\text { tity }\end{array}$ & Case & Quantity & Case \\
\hline \multirow{3}{*}{$36 \mathrm{~F}$} & 2 & $\begin{array}{l}\text { Case } \\
\text { DC-2 }\end{array}$ & 2 & $\begin{array}{c}\text { Case } \\
\text { OIL-2 }\end{array}$ & $2(1+1)$ & $\begin{array}{c}\text { Case } \\
\text { Dual-2 }\end{array}$ \\
\hline & 4 & $\begin{array}{l}\text { Case } \\
\text { DC-4 }\end{array}$ & 4 & $\begin{array}{c}\text { Case } \\
\text { OIL-4 }\end{array}$ & $4(2+2)$ & $\begin{array}{l}\text { Case } \\
\text { Dual-4 }\end{array}$ \\
\hline & 8 & $\begin{array}{l}\text { Case } \\
\text { DC-8 }\end{array}$ & 8 & $\begin{array}{c}\text { Case } \\
\text { OIL-8 }\end{array}$ & $8(4+4)$ & $\begin{array}{c}\text { Case } \\
\text { Dual-8 }\end{array}$ \\
\hline \multirow{3}{*}{$45 \mathrm{~F}$} & 2 & $\begin{array}{l}\text { Case } \\
\text { DC-2 }\end{array}$ & 2 & $\begin{array}{c}\text { Case } \\
\text { OIL-2 }\end{array}$ & $2(1+1)$ & $\begin{array}{c}\text { Case } \\
\text { Dual-2 }\end{array}$ \\
\hline & 4 & $\begin{array}{l}\text { Case } \\
\text { DC-4 }\end{array}$ & 4 & $\begin{array}{c}\text { Case } \\
\text { OIL-4 }\end{array}$ & $4(2+2)$ & $\begin{array}{c}\text { Case } \\
\text { Dual-4 }\end{array}$ \\
\hline & 8 & $\begin{array}{l}\text { Case } \\
\text { DC-8 }\end{array}$ & 8 & $\begin{array}{c}\text { Case } \\
\text { OIL-8 }\end{array}$ & $8(4+4)$ & $\begin{array}{c}\text { Case } \\
\text { Dual-8 }\end{array}$ \\
\hline \multirow{3}{*}{$54 \mathrm{~F}$} & 2 & $\begin{array}{l}\text { Case } \\
\text { DC-2 }\end{array}$ & 2 & $\begin{array}{c}\text { Case } \\
\text { OIL-2 }\end{array}$ & $2(1+1)$ & $\begin{array}{c}\text { Case } \\
\text { Dual-2 }\end{array}$ \\
\hline & 4 & $\begin{array}{l}\text { Case } \\
\text { DC-4 }\end{array}$ & 4 & $\begin{array}{l}\text { Case } \\
\text { OIL-4 }\end{array}$ & $4(2+2)$ & $\begin{array}{c}\text { Case } \\
\text { Dual-4 }\end{array}$ \\
\hline & 8 & $\begin{array}{l}\text { Case } \\
\text { DC-8 }\end{array}$ & 8 & $\begin{array}{c}\text { Case } \\
\text { OIL-8 }\end{array}$ & $8(4+4)$ & $\begin{array}{c}\text { Case } \\
\text { Dual-8 }\end{array}$ \\
\hline
\end{tabular}

43). The 54-story building shows a reduction of $7 \%$ to $35 \%$ through the placement of 8 control columns (DC), $10 \%$ to $30 \%$ through the placement of 8 oil dampers (OIL), and $10 \%$ to $35 \%$ through the placement of both 4 DCs and 4 OILs (Dual). The drift angles of all stories tend to be reduced through OIL whereas the angle reduction rates of the top and low stories comparatively differ through DC. Through Dual, the story drift angles tend to lie between DC and OIL.

\subsubsection{Reduction ratio of story drift angles}

\section{(1) Horizontal displacements of building}

The ratios of Horizontal displacements at the center of gravity of building to the displacements of Case 0 (without any damage fuses) are compared in Fig. 44. 
For designing damage fuses, using 4,8 and 10 damage fuses can roughly reduce the displacements by $5 \%, 10 \%$ and $15 \%$, respectively.

(2) Reduction ratio of story drift angle

Figure 45 shows the relationships between the reduction ratios $(\gamma)$ of story drift angles (ratios to those with-

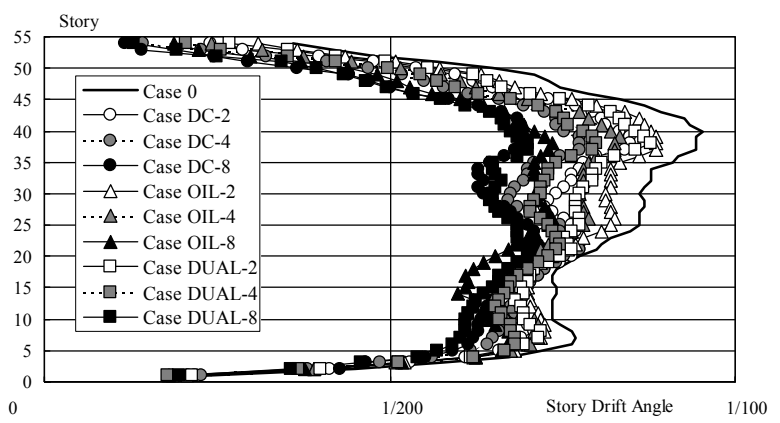

(a) 54-Story building

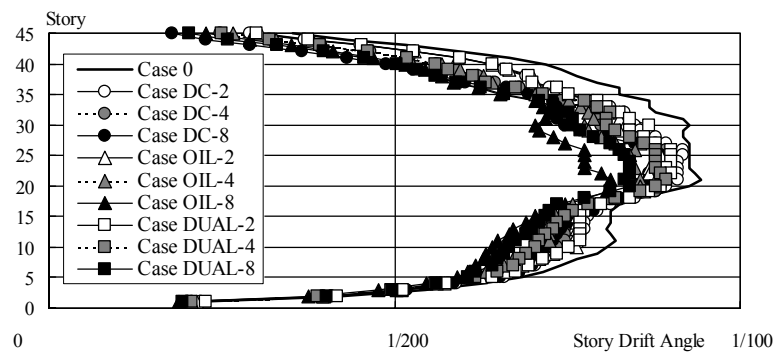

(b) 45-Story building

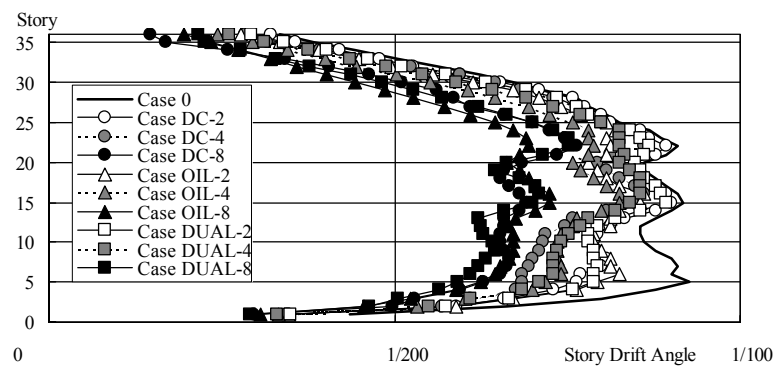

(c) 36-Story building

Fig. 43 Comparison of story drift angle for earthquake response analysis. out any damage fuses) and ratios of total cumulative energies (PE) for 9th, 29th and 42nd stories of the 54-story building. PE is the ratio of the cumulative energy absorption of damage fuses to one of its frames. $\gamma$ is calculated through story shear deflection. Therefore it does not include the flexural deflection by axial deformations of columns. Figure 45, which demonstrates the correlation of $\gamma$ with the PE. $\gamma$ - PE relationships, shows that for DC, the values of $\gamma$ differ when the values of $P E$ are large. For the same values of $\mathrm{PE}$, the values of $\gamma$ from DC tend to be larger than the values from OIL. The values from Dual tend to lie between DC and OIL. The reason for these tendencies is that installing DC (stud type) not only adds hysteresis damping but also reduces the story drift angles by increasing the rigidity of building.

\section{Construction practice of damage fuses}

\subsection{Examples of high-rise RC buildings}

(1) Practical use of control columns

Control columns have already been selected as damage fuses in nine high-rise $\mathrm{RC}$ buildings. The use of control columns in a number of additional projects is also currently being considered. The condominiums that have already installed control columns range between 19 and 54 stories. This chapter introduces the characteristics of the control columns selected for two projects (out of 9 projects). Low-yield-point steel panel dampers have been used as the control columns.

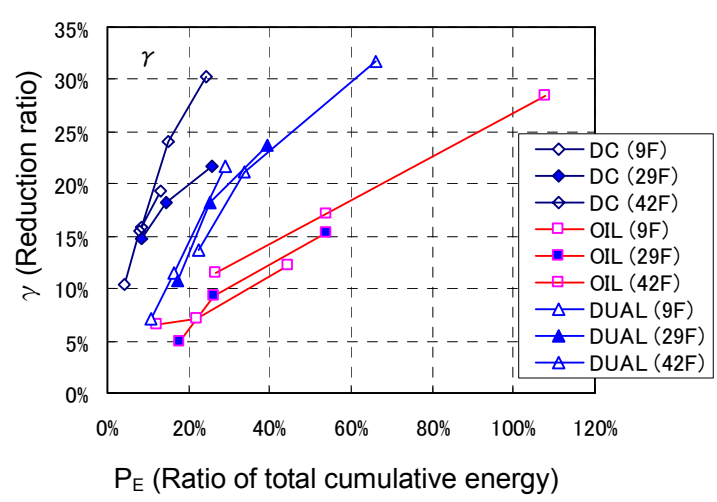

Fig. $45 \gamma-P_{E}$ relationships.
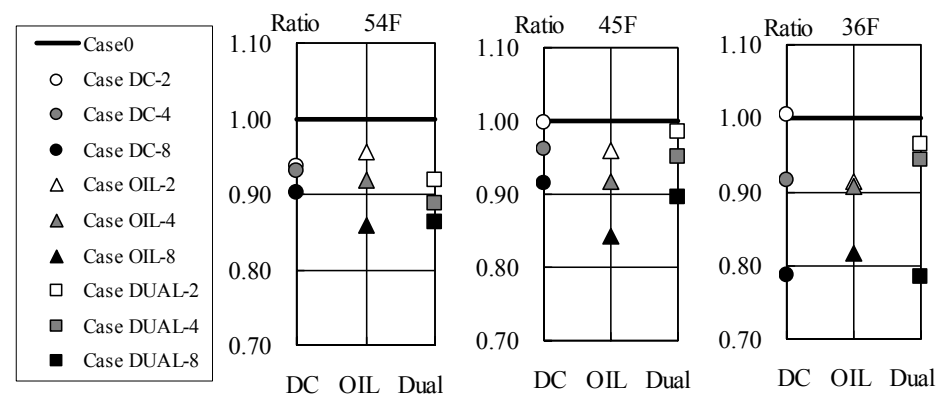

Fig. 44 Building response displacement ratio to non-response control. 
(2) Control columns in 36-story condominiums

The first example is the twin towers of 36-story condominiums located in Toyosu, Tokyo (Fig. 46). These buildings employ a central core type floor plan. The control columns are located around the staircase in the common area at the center of the plane (Fig. 47).

\section{(3) Control columns in 54-story condominiums}

The second example consists of a 54-story condominium and a 45-story condominium located in Shinonome, Tokyo (Fig. 48). These buildings employ a central void type floor plan. The control columns are located around

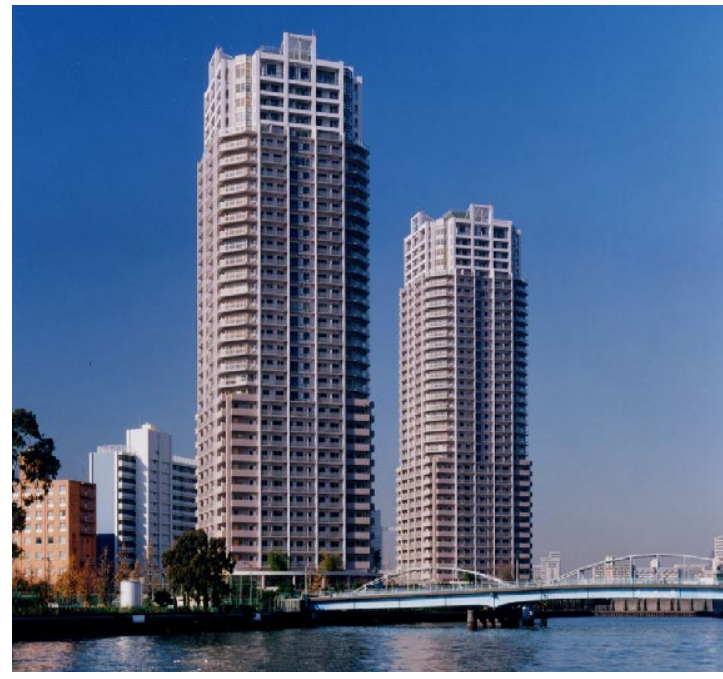

Fig. 46 View of 36-story buildings.

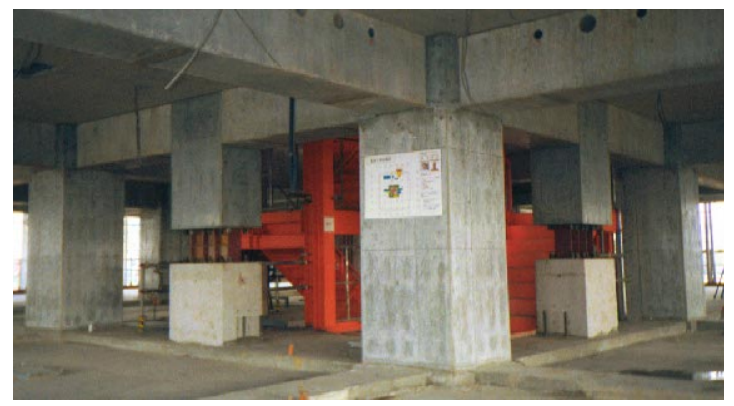

Fig. 47 Control columns in central core.

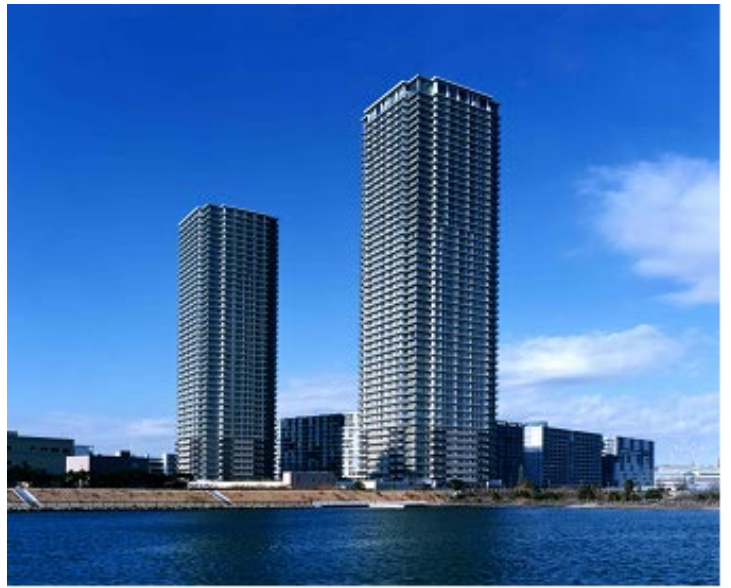

Fig. 48 View of 54-story and 45-story buildings. the central void of the inside corridor in the common area (Fig. 49).

\subsection{Controlling effect of damage fuse by simu- lation}

The controlling effects of damage fuses against strong earthquakes are presented for the 54-story building. Each typical floor has six control columns in each direction (thus a total of 12 control columns). Figure 50 shows the comparison of the response story drift angles for the building with control columns and the building without control columns. The earthquake inputs consist of both Center-wave (Center-wave 1996) and possible earthquake that quite rarely occur (notified code-wave). The response drift angles with control columns are reduced by $20 \%$ to $30 \%$ compared with those without control columns, whereas the maximum response drift angle without control columns is less than $1 / 100$.

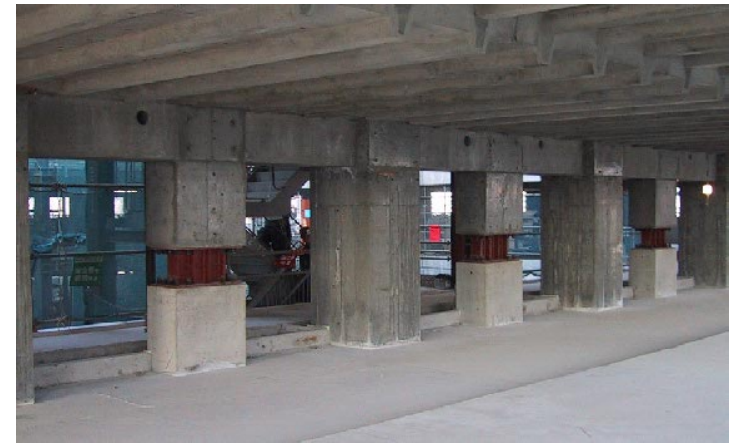

Fig. 49 Control columns in central frame.

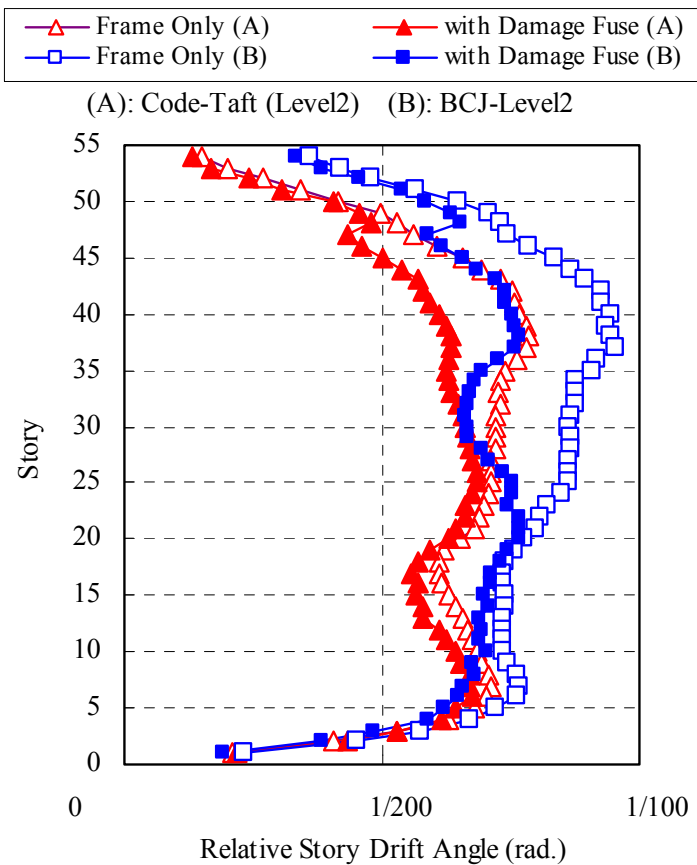

Fig. 50 Comparison for earthquake response analyses of 54-story building with and without damage fuses. 


\section{Conclusions}

This paper describes the objectives of damage control technology and presents the findings of experimental and analysis studies on high-rise RC buildings. This paper also introduces examples of high-rise RC buildings that use damage control technology.

(1) The design method of high-rise RC buildings with damage control devices is presented.

(2) Based on the experimental results, the restoring force characteristics of control columns of low-yield-point steel panels are thoroughly evaluated and demonstrate a great capacity for energy dissipation. An analysis model for control columns is also proposed.

(3) Based on the experimental results of static and dynamic loadings, the addition of damage fuses RC frames can increase the energy dissipation capacity of RC frames. The analysis models for frames with damage fuses are also presented.

(4) The non-linear response analyses show that adding damage fuses can reduce the displacements of high-rise RC buildings caused by earthquakes.

(5) Existing high-rise RC buildings with control columns of low-yield-point steel panels are outlined. The controlling effect of damage fuses against strong earthquakes is proposed by simulations.

\section{Acknowledgements}

Testing of frames with damage fuses was conducted as part of the Toda Corporation-Nishimatsu Construction Cooperative Research Program. Testing of RPC frames was done jointly with the R\&D Center, Taiheiyo Cement Corporation. The writers wish to express sincere gratitude to the members of the program for their support for the experimental investigation.

\section{References}

Izumi, N., Hayashi, M., Hamada, M., Todo, M., Kaneko, O. and Ooi, T. (2001). "Seismic design method of super high performance RC high-rise housing system." Summary of Technical Papers of Annual Meeting of Architectural Institute of Japan, 655-662. (in Japanese)

Izumi, N., Takenaka, H., Chiba, O. and Asega, H. (2002). "A Study on seismic performance of RC frame with damping member." Proceedings of Japan Concrete Institute, 24 (2), 1057-1062. (in Japanese)

Izumi, N., Takenaka, H., Chiba, O. and Asega, H. (2003). "A Study on seismic performance of RC frame with visco-elastic damping member." Proceedings of Japan Concrete Institute, 25 (2), 1363-1368. (in Japanese)

Takeda, T., Sozen, M. A. and Nielsen, N. M. (1970). "Reinforced concrete response to simulated earthquakes." Journal of Structural Division, ASCE, 96 (ST12).

Center Wave (1996). The Building Center of Japan (BCJ). Available from: $<$ http://www.bcj.or.jp $>$. 